\title{
A STUDY OF THE GEOLYCOSA PIKEI COMPLEX IN THE SOUTHEASTERN UNITED STATES
}

\author{
By \\ JOHN DAVID McCRONE
}

\begin{abstract}
A DISSERTATION PRESENTED TO THE GRADUATE COUNCIL OF THE UNIVERSITY OF FLORIDA IN PARTIAL FULFILLMENT OF THE REQUIREMENTS FOR THE DEGREE OF DOCTOR OF PHILOSOPHY
\end{abstract}

UNIVERSITY OF FLORIDA

August, 1961 


\section{ACKNOWLEDGEMENTS}

I wish to thank Dr. H. K. Wallace, the chairman of my graduate committee, for his initial guidance in selecting this problem and his direction, encouragement and many valuable suggestions throughout the course of the investigation.

I am also grateful to those who have served as members of my graduate committee. These include: Doctors A. F. Carr, A. M. Laess1e, J. R. Redmond, T. J. Walker and H. M. Wallbrunn. Dr. M. J. Fouquette gave valuable aid in the preparation of the illustrations. Fellowships from the College of Arts and Sciences, University of Florida and from the Southern Regional Fund provided financial aid during the course of this investigation.

I am especially grateful to my wife and mother for their encouragement and secretarial aid. 
TABLE OF CONTENTS

Page

ACKNOWLEDGEMENTS.

LIST OF TABLES

LIST OF ILLUSTRAT IONS......................... iv

INTRODUCTION....................................... 1

METHODS....................................... 3

SPECTES CRITERIA............................... 6

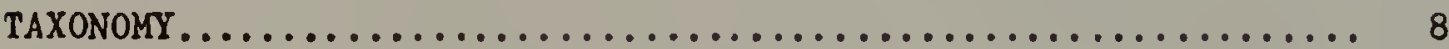

Geolycosa pikei $(\operatorname{Mar} x) \ldots \ldots \ldots \ldots \ldots \ldots \ldots \ldots \ldots \ldots$

Geolycosa xera new species..................... 9

Geolycosa xera xera new subspecies............... 26

Geolycosa xera archboldi new subspecies............. 27

Geolycosa patellonigra Wallace................. 29

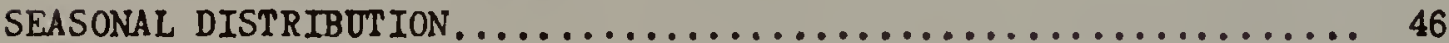

G. plke1............................. 46

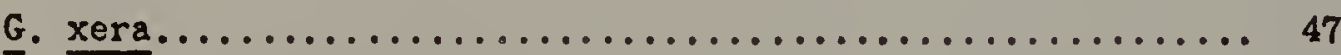

G. patellonigra......................... 47

Discussion................................. 53

POST-PLIOCENE HISTORY OF THE SOUTHEASTERN COASTAL PLAIN....... 56

PRESENT DISTRIBUTION AND HABITAT RELATIONS $\ldots \ldots \ldots \ldots \ldots \ldots \ldots .65$

CONCLUSIONS CONCERNDNG THE EVOLUTIONARY HISTORY OF THE COMPLEX.. 71

LITERATURE CITED................................. 77

BIOGRAPHICAL SKETCH............................ 80 


\section{LIST OF TABLES}

Table

Page

1. Length of the carapace of female . xera $\ldots \ldots \ldots \ldots \ldots 17$

2. Length of the epigynum of female $\mathrm{G}$. xera.............. 17

3. Length of the carapace of female G. patellonigra..........38

4. Length of the epigynum of female G. patellonigra.........41

5. Percentage of female G. patellonigra with light patellae on legs III and IV...................... 44

6. Observed seasonal population composition of $\underline{G}$. pikei......4 46

7. Observed seasonal population composition of $\mathrm{G}$. xera.......47

8. Observed seasonal population composition of $G$. patellonigra in Gilchrist, Clay, Putnam and western Volusia counties.

9. Observed seasonal population composition of $G$. patellonigra in Marion and Hillsborough counties.........49

10. Observed seasonal population composition of $\mathbf{G}$. patellonigra in Levy, Alachua, Hernando and Sumter counties........................................

11. Observed seasonal population composition of $G$. patellonigra in western Volusia, Brevard and Indian River counties.

12. Estimated duration and associated shorelines of the

Post-P1iocene Interglacial stages. 


\section{LIST OF ILLUSTRATIONS}

Figure

1. Comparison of the male palpal organs of $\mathbf{G}$. pikei, G. patellonigra and $G$. xera (holotype)..........13

2. Map showing the localities from wich the samples of the various populations of $G$. xera were obtained......... 16

3. Modified Dice-Leraas symbols showing the variation in the length of the carapace of female G. xera.......... 19

4. Symbols showing the variation in the length of the epigynum of female $\mathrm{G}$. xera........................ 21

5. Frequency distributions showing the variation in color pattern on the ventral surface of legs $I$ and II In female $\mathrm{G}$. xera........................... 24

6. Localities from which samples of the various populations of $\mathrm{G}$. patellonigra were obtained............ 35

7.. Symbols showing the variation in the length of the carapace of female G. patellonigra............... 37

8. Symbols showing the variation in the length of the epigynum of female $\underline{G}$. patellonigra.

9. Frequency distributions showing the variation in color pattern on the ventral surface of legs $I$ and II in female G. patellonigra.

10. Map showing the geographic variation in breeding season in G. patellonigra.

11. Map showing the approximate land areas of the Okefenokee Sea.............................. 58

12. Map showing the approximate land areas of the

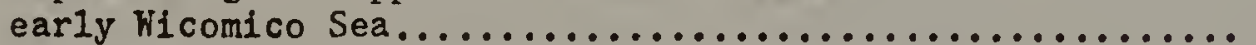

13. Map showing the approximate shoreline of the Panlico Sea..................................

14. Map showing the distribution of the members of the pikei complex in Florida and Georgla. 


\section{INTRODUCT ION}

In his revision of the burrowing wolf spider genus Geolycosa Wallace (1942) described a new species, patellonigra. This species was confined to Florida and inhabited inland, dune-like areas supporting sand-pine scrub or sandhill vegetation. Its morphology and habitat preferences were similar to those of G. pikei (Marx), a specics inhabiting sandy beaches and inland sandhills along the Atlantic seaboard from Massachusetts south to northern Georgia. These similarities led Wallace to regard patellonigra as a southern derivative of pikei. However, the exact relationship between pikei and patellonigra was obscure because of the lack of male specimens from the Carolinas and Georgia. The few female specimens from this area were arbitrarily assigned to pikei. The populations included under the name patellonigra showed a great deal of variation in morphology and seasonal distribution. Because of this variation, Wallace felt that these populations might constitute a complex rather than a single species.

This diversification in the southern part of the range is striking in view of the relatively uniform topography of the southeastern Coasta1 P1ain. Several authors (Carr, 1940; Hubbe11, 1954, 1956; Highton, 1956; Neil, 1957) have noted a similar diversification in other groups of animals which inhabit this area. They have sought an explanation in the Post-P1iocene history of the area. MacNeil (1950) has published a map of the Post-P1iocene shorelines of Florida and Georgia 
which shows extensive insulation in this area. Recently, Laessle (1958) was able to demonstrate that the distribution of sand-pine scrub and sandhill vegetation can be closely correlated with the Post-Pliocene shorelines plotted by MacNeil.

The present study is an attempt to clarify the taxonomic status and seasonal distribution of the group of populations which hereafter will be referred to as the pikei complex, and (in view of the restriction of this complex to beaches, sandhills and sand-pine scrub) to determine whether an explanation of its present status and distribution can be obtained by a consideration of the Post-Pliocene history of the area. 
METHODS

The specimens used in this study were preserved in 70 per cent or 95 per cent ethyl alcohol and were studied while under alcohol. A data sheet was compiled for each adult specimen, and the following information was recorded: 1) date of collection, 2) locality, 3) type of habitat, 4) a drawing of the ventral color pattern, 5) ecological and life history notes and 6) two measurements. The measurements recorded for the females were the length of the carapace and the length of the epigynum. The length of the carapace was measured from the anterior margin of the posterior median eyes to the posterior edge of the carapace. The length of the epigynum was measured from the posterior end of the guide to the anterior end of the furrow of the epigynum. Measurements recorded for the males were the length of the carapace and the length of the cymbium.

The length of the carapace is the best indicator of body size. The total body length varies widely because of fluctuations in the size of the abdomen. These fluctuations are due to various factors such as extent of ovarian development and the nutritional status of the animal.

During a preliminary study additional measurements were taken, and several ratios were constructed from them. The measurements taken were the width of the carapace, the width of epigynum, the height of the carapace, the width of the cymbium and the lengths of the 1 eg 
segments. These measurements and ratios either showed no significant geographic variation or were directly correlated with the length of the carapace or the length of the epigynum.

The carapace measurements were made with a special measuring microscope and are expressed in millimeter units. The genitalic measurements were made with an ocular micrometer. Each micrometer unit was equal to $0.033 \mathrm{~mm}$. Since the readings were taken to the nearest micrometer unit, the genitalic measurements are expressed in micrometer units instead of millimeters to avoid the erroneous impression that the genitalic measurements are accurate to one thousandth of a millimeter.

Drawings of the ventral color pattern were made only from freshly preserved specimens because long preservation results in the loss of pigment in some areas. These drawings are stylized since only areas of black pigmentation on the legs were recorded, and no attempt was made to render the cuticle color or the shadings of gray on the sternum and venter. Areas on the legs devoid of black pigment are shown as being white instead of their normal buff color. Colors given in the descriptions were determined by comparison with Maerz and Paul (1930), under the artificial yellow light of an ordinary microscope 1amp.

A11 of the specimens used in this study were collected either by Dr. H. K. Wallace of the Biology Department of the University of Florida or the author. A11 of the collection sites were visited personally by the author so that field notes are available for all of 
the locality records. The locality records given in the text are accompanied by a catalog number. The initials HKW or JMCC before the catalog number refer to the field notes of Dr. Wallace and the author, respectively.

It is difficult to collect males because they mature only at certain seasons and have a short life span. For this reason, penultimate males were brought into the laboratory and raised to maturity. Comparison of these reared males with those collected in the wild showed no apparent differences. 


\section{SPECIES CRITERIA}

The taxonomic treatment of allopatric populations which are separated by distributional gaps has been a source of controversy for many years. Several yardsticks have been proposed to help determine, in the absence of direct evidence of reproductive isolation, whether these populations should be treated as species or subspecies (Mayr et al., 1953). All of these yardsticks are based on an observed correlation between morphological difference and reproductive isolation. One approach is to compare the degree of difference between two good sympatric species with the degree of difference existing between the allopatric populations. Character displacement (Wilson and Brown, 1956) would introduce a potential source of error into this yardstick. According to this concept, when the ranges of two closely related species partially overlap the differences between the two species are accentuated in the area of sympatry. These differences tend to disappear or lessen in the allopatric portions of the range. However, this effect would lead to conservatism rather than excessive splitting.

$$
\text { Another approach is to compare the degree of difference }
$$

between the most divergent, intergrading subspecies of a widespread species with the degree of difference between the allopatric populations. Both of these comparisons are best made within the same genus.

In this study the first approach proved most fruitful. There was not enough available information on infraspecific variation in the 
genus Geolycosa or in the family Lycosidae to warrant using the second approach. A review of the morphological criteria used to differentiate sympatric species in the genus Geolycosa and other lycosid genera showed that the genitalia provide the most reliable taxonomic characters. The female epigynum, however, is not as useful as the male palpal organ. In his recent study of the lapidicina group of the genus Pardosa, Barnes (1959) noted that the structure of the male palpal organ was the most valuable character for the separation of species. The structure of the female epigynum was very similar in all the species, and he had difficulty in separating the females. Wallace (1942) in his study of the lenta group of the genus Lycosa had similar difficulty separating the females of a subgroup of three species even though the male palpal organ provided good separation.

In view of these findings, the degree of difference in the morphology of the male palpal organ was considered the most important species criterion in this investigation. A study of the epigynum and ventral color pattern provided good separation of the females. 


\section{TAXONOMY}

A consideration of the morphology, ecology and zoogeography of the allopatric populations making up the pikei complex has resulted in the recognition of three species and two subspecies. Two of the species, $\underline{G}$. pikei (Marx) and $\underline{G}$. patellonigra Wallace, have been previous $1 y$ described and their status is confirmed. $\underline{G}$. xera and its two subspecies $\underline{G}$. xera xera and $\underline{G}$. xera archboldi are described as new.

\section{Geolycosa pikei (Marx)}

New Records.-Georgia: Burke Co.: Keysville, Aug. 17, 1960, Cat. JMCC 61-1, sandy field in turkey oak - pen. males, 2 pen. females; $6 \mathrm{mi}$. west of Swainsboro on U. S. 80, Aug. 17, 1960, Cat. JMCC 61-2, turkey oak - 7 pen. fema1es. South Carolina: Lexington Co.: Columbia, July 20, 1946, Cat. HKW 1230, turkey oak - 1 female, several imm.

Geographic Distribution.-At1antic Coasta1 Plain from northern Georgia to Massachusetts and on adjacent islands.

Observations and Remarks. -The penultimate males collected on August 17, 1960, at Keysville, Georgia,were brought into the 1aboratory alive. Two of the twelve were successfully raised to maturity. Their palpal organs were identical to those of males from the northern part of the range of pikei and differed markedly from those of males from a11 parts of the range of patellonigra. 
An extensive search of the area 1ying between the southern limit of pikei's range and the northern limit of patellonigra's range (Figure 14) failed to produce any representatives of either species. The absence of these spiders from this area is probably due to the lack of suitable habitat. A large portion of the area is occupied by the Okefenokee Swamp and great expanses of flatwoods. The small patches of sandhill vegetation in the area are found only along the banks, usually the northern, of the easterly flowing rivers. These do not present the usual dune-like topography of the areas inhabited by spiders of the pikei complex.

\section{Geolycosa xera new species}

Holotype.-Male, from scrub eight miles north of Avon Park, Polk Co., Florida, on U. S. 27, Nov. 21, 1960, Cat. JMcC 65; allotype, a female with the same data: both will be deposited at the American Museum of Natural History, New York.

Description of Holotype.-In alcohol - Carapace uniform, no median stripe; covered with silvery pubescence; central area beneath pubescence near Windsor Tan; sides darker, near Leaf Mold. Dorsum of abdomen covered with silvery pubescence; near Rose Beige beneath; no markings; sides of abdomen black. Venter with a median dark band, sides 1ight. Sternum, coxae, endites and labium dusky; sternum 1ighter than rest; femur of palpus dusky; patella and tibia 1ight. Femora I-II, patellae I-IV, tibia I, proximal half of tibia II, and proximal quarter of tibia III-IV black beneath; femora III-IV dusky beneath; other segments light. Chelicerae same color as sides of carapace. 
Carapace longer than wide $(6.1 \mathrm{~mm} . / 3.9 \mathrm{~mm}),. 3.0 \mathrm{~mm}$. high; width of head $3.3 \mathrm{~mm}$. Posterior eye quadrangle wider than long $(2.0 \mathrm{~mm} . / 1.3 \mathrm{~mm}$.$) , median eyes the same size as laterals (0.5 \mathrm{~mm} . /$ $0.5 \mathrm{~mm}$.$) . Posterior median row wider than anterior row (1.5 \mathrm{~mm} . /$ $0.7 \mathrm{~mm}$.$) ; anterior row of eyes slightly procurved, eyes equally$ spaced, medians larger than laterals $(0.3 \mathrm{~mm} . / 0.2 \mathrm{~mm}$ ). Distance from top of posterior median eyes to clypeus $1.0 \mathrm{~mm}$. Palpal segments: femur $1.9 \mathrm{~mm}$, patella $0.9 \mathrm{~mm}$., tibia $1.2 \mathrm{~mm}$, tarsus and claws $2.0 \mathrm{~mm}$. Distance from posterior edge of epigynum to anterior end of furrow of epigynum $0.5 \mathrm{~mm}$. Legs 4123 .

\begin{tabular}{|c|c|c|c|c|c|c|}
\hline & Femur & Patella & Tibia & Metatarsus & Tarsus & Total \\
\hline I & 4.5 & 1.4 & 4.0 & 3.9 & 2.7 & 16.5 \\
\hline II & 4.2 & 1.3 & 3.5 & 3.8 & 2.6 & 15.4 \\
\hline III & 3.7 & 1.4 & 2.7 & 3.6 & 2.5 & 13.9 \\
\hline IV & 4.8 & 1.4 & 4.4 & 4.9 & 3.0 & 18.5 \\
\hline
\end{tabular}

Description of Allotype.-In alcohol - Carapace uniform, no median stripe; rubbed clear of most of whitish-gray pubescence; head near Orange Chrome, rest of carapace near Burnt Sienna. Dorsum of abdomen uniform, no markings, near Rose Beige; beset with numerous black bristles; anterior part of abdomen surrounding pedicel black. Venter without median dark band; same color as dorsum; beset with numerous black bristles. Sternum, coxae, endites, and labium light; all segments of palpus light. Femora I-II, patellae I-II, tibia I, and proximal half of tibia II black beneath; other segments light. Chelicerae near Burnt Sienna.

Carapace Ionger than wide $(6.1 \mathrm{~mm} . / 3.9 \mathrm{~mm}),. 3.0 \mathrm{~mm}$. high; 
width of head $3.3 \mathrm{~mm}$. Posterior eye quadrangle wider than 1ong $(2.0 \mathrm{~mm} . /$ $1.3 \mathrm{~mm}$.$) , median eyes the same size as laterals (0.5 \mathrm{~mm} . / 0.5 \mathrm{~mm}$.$) .$ Posterior median row wider than anterior row $(1.5 \mathrm{~mm} . / 0.7 \mathrm{~mm}$.); anterior row of eyes slightly procurved, eyes equally spaced, medians larger than laterals $(0.3 \mathrm{~mm} . / 0.2 \mathrm{~mm}$.). Distance from top of posterior median eyes to clypeus $1.0 \mathrm{~mm}$. Palpal segments: femur $1.9 \mathrm{~mm}$, patella $0.9 \mathrm{~mm}$. , tibia $1.2 \mathrm{~mm}$, tarsus and claws $2.0 \mathrm{~mm}$. Distance from posterior edge of epigynum to anterior end of furrow of epigynum $0.5 \mathrm{~mm}$. Legs 4123 .

\begin{tabular}{|c|c|c|c|c|c|c|}
\hline & Femur & Patelia & Tibia & Metatarsus & Tarsus & Tota1 \\
\hline I & 3.9 & 1.4 & 3.1 & 2.8 & 2.1 & 13.3 \\
\hline II & 3.5 & 1.4 & 2.7 & 2.4 & 2.0 & 12.0 \\
\hline III & 3.1 & 1.3 & 2.2 & 2.8 & 2.2 & 11.6 \\
\hline IV & 4.1 & 1.4 & 3.6 & 4.0 & 2.7 & 15.8 \\
\hline
\end{tabular}

Diagnosis.-Figure 1 shows a comparison of the male palpal organs of G. pikei, G. patellonigra and $\underline{G}$. xera. These drawings were made to scale by placing a squared grid in one ocular of a binocular microscope. The shape of the median apophysis shows very little infraspecific variation and is the most useful character for the separation of these species.

Geographic Variation.-The structure and general conformation of the male and female genitalia is uniform throughout the range. Although only a distance of 77 miles separates the northern and southern limits of the range, there is considerable geographic variation in the length of the carapace, the length of the epigynum and the ventral color pattern. The following analysis of variation is restricted to adult females because of the small number of adult males available from each 


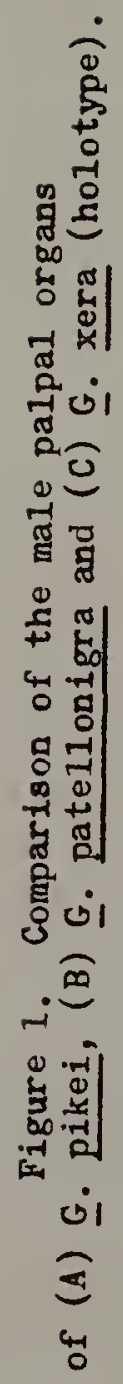



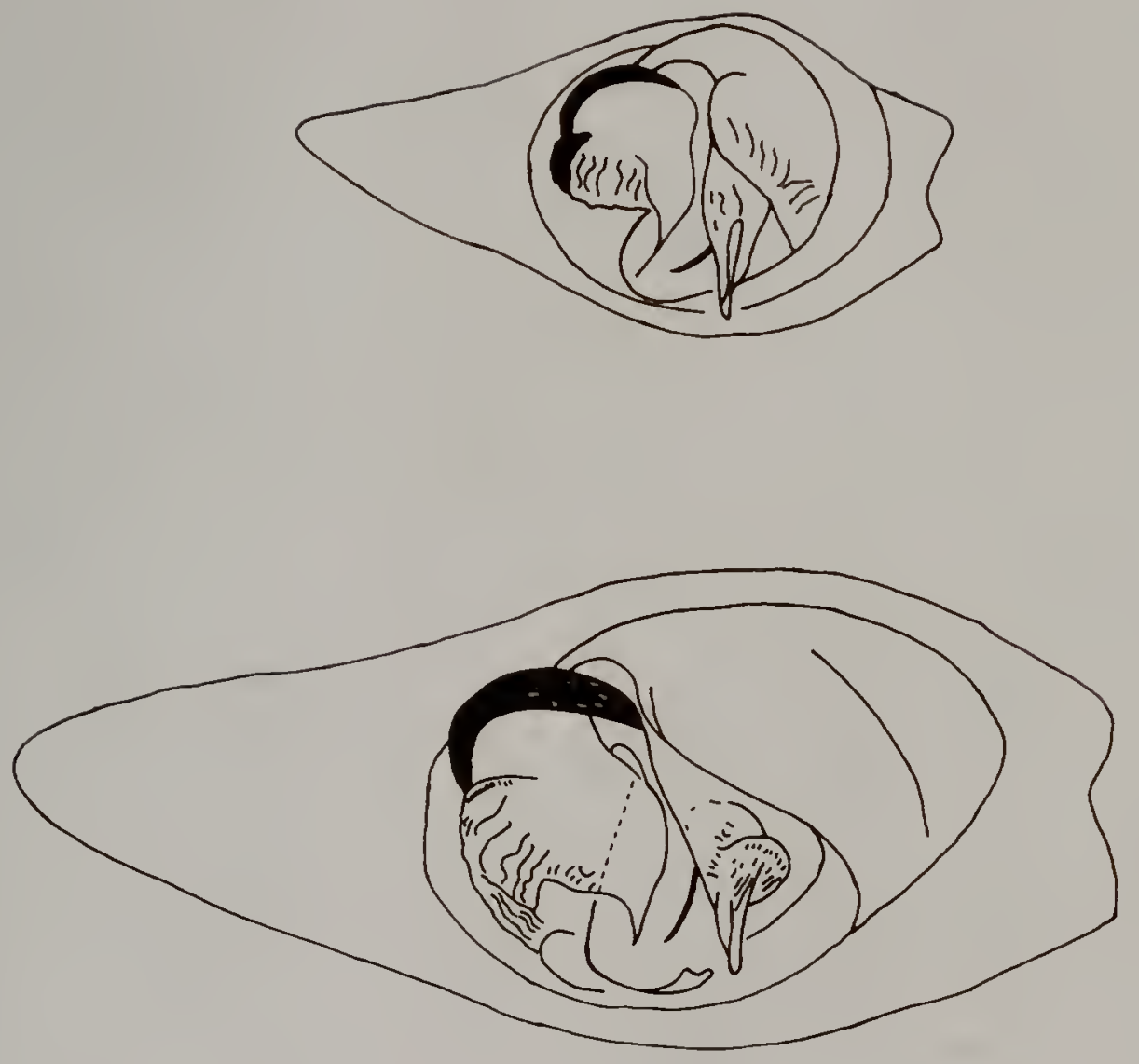

o

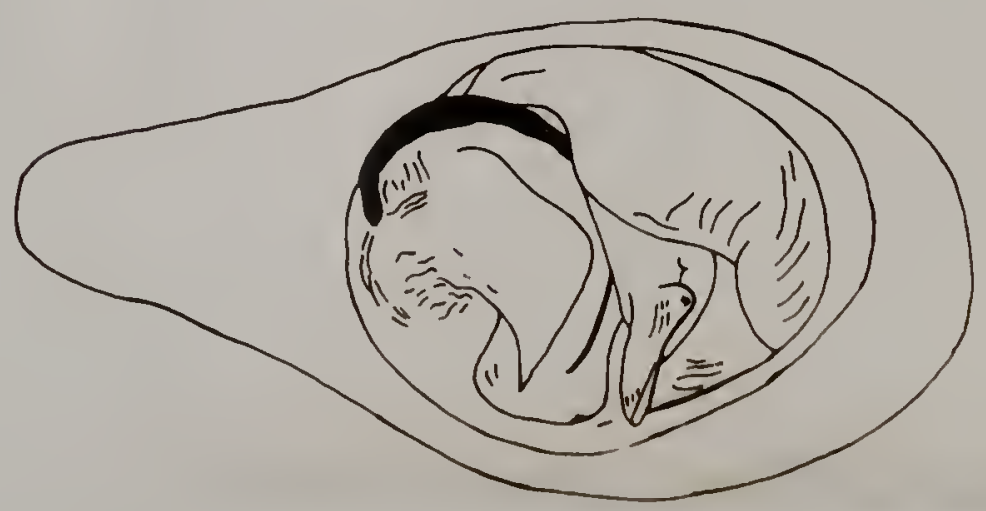


1ocality. The carapace length and the ventral color pattern of the males varies in the same manner as those of the females.

A11 of the available specimens were not used in this study. In order to minimize the danger of lumping specimens from different populations, a large series of specimens was collected from each of several small areas throughout the range of the species. Each of these series was designated a sample and assigned a number. Figure 2 shows the areas from which the samples were drawn. The specific localities included in the samples and the number of specimens taken from each locality are listed below. The number of specimens are in parentheses.

Sample 1. Seminole Co.: Geneva (11). Volusia Co.: Enterprise (2); $2.6 \mathrm{mi}$. E of 0steen (10); DeBary (4).

Samp1e 2. Lake Co.: $0.5 \mathrm{mi} . \mathrm{N}$ of junction of State Road 561 and State Road 448 on 561 (6). Orange Co.: $5.5 \mathrm{mi}$. S of Apopka on State Road 437 (2); $3.9 \mathrm{mi}$. SE of Apopka on U. S. 441 (1). Polk Co.: $17 \mathrm{mi}$. N of junction of U. S. 27 and U. S. 92 on 27 (5).

Sample 3. Polk Co.: $8 \mathrm{mi}$. N of Avon Park on U. S. $27(45)$.

Sample 4. Highlands Co.: $4 \mathrm{mi}$. E of Avon Park (9).

Sample 5. Highlands $C_{0}$ : $2 \mathrm{mi}$. S of Avon Park on U. S. $27(17)$.

Sample 6. Highlands Co.: $9.5 \mathrm{mi}$. $\mathrm{N}$ of junction of U. S. 27 and State Road 621 on 27 (8); junction of U. S. 27 and U. S. 98 (4); $4.8 \mathrm{mi}$. S of junction of U.S. 27 and U. S. 98 on $27(7)$.

Sample 7. Highlands Co.: $1.2 \mathrm{mi}$. W of junction of U. S. 27 and State Road 70 on 70 (25). 
Figure 2. Localities from which the samples of the various populations of $G$. vera were obtained. The outlined area represents the total know distribution. 


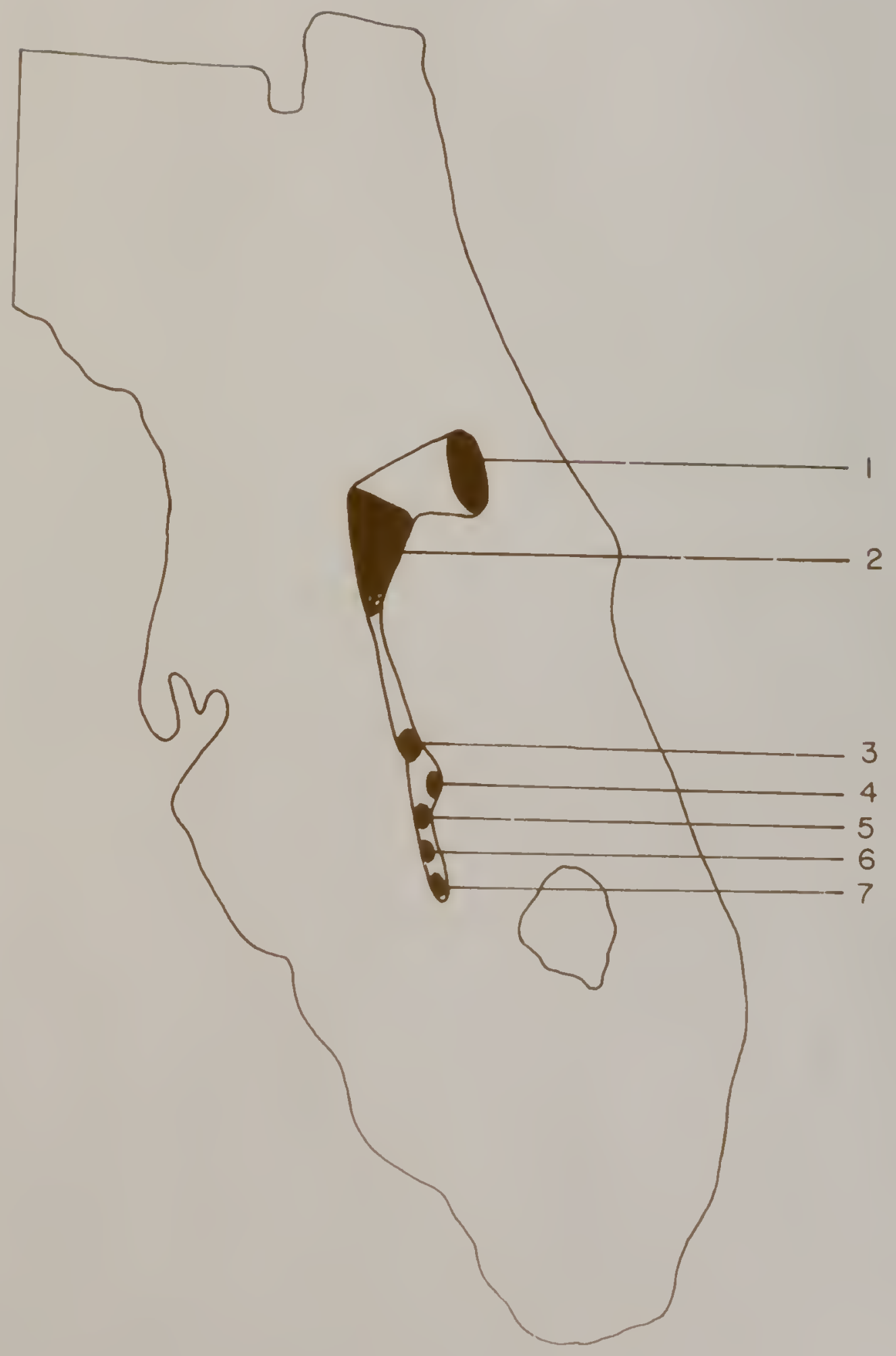


Figure 3 illustrates the trend of variation in the length of the carapace throughout the range. With the exception of sample 4 there is a clinal decrease in length from north to south. A onetailed statistical comparison of the means of samples 3 and 4 was made to determine whether the mean of sample 4 is significantly larger. This gave a $t$-value of $2.048(0.01<P<0.025)$. Sample 4 consists of only nine specimens and is the smallest sample. Since the sample variance is large, this sample may not represent a real break in the cline. Figure 4 shows there is also a clinal decrease from north to south in the length of the epigynum.

Table 1.-Length of carapace of female $G$. xera

\begin{tabular}{cccccc}
\hline \hline $\begin{array}{l}\text { Sample } \\
\text { number }\end{array}$ & $\begin{array}{c}\text { Sample } \\
\text { size }\end{array}$ & Range & Mean & $\begin{array}{c}\text { 95\% Confidence } \\
\text { interva1 }\end{array}$ & S. D. \\
\hline 1 & 27 & $5.7-8.8$ & 6.9 & $6.6-7.2$ & 0.719 \\
2 & 15 & $5.3-8.7$ & 6.7 & $6.1-7.3$ & 1.034 \\
3 & 45 & $4.5-8.0$ & 6.0 & $5.7-6.3$ & 0.874 \\
4 & 9 & $5.1-8.4$ & 6.7 & $5.8-7.6$ & 1.221 \\
5 & 17 & $4.8-7.5$ & 5.8 & $5.4-6.2$ & 0.828 \\
6 & 19 & $4.6-6.5$ & 5.6 & $5.3-5.9$ & 0.550 \\
7 & 25 & $4.2-7.0$ & 5.3 & $5.0-5.6$ & 0.777 \\
\hline
\end{tabular}

Table 2.-Length of the epigynum of female $\underline{G}$. xera

\begin{tabular}{lccccc}
\hline $\begin{array}{l}\text { Sample } \\
\text { number }\end{array}$ & $\begin{array}{c}\text { Sample } \\
\text { size }\end{array}$ & Range & Mean & $\begin{array}{c}95 \% \text { Confidence } \\
\text { interval }\end{array}$ & S. D. \\
\hline 1 & 27 & $14-18$ & 16.1 & $15.7-16.5$ & 1.100 \\
2 & 15 & $14-18$ & 16.5 & $15.7-17.3$ & 1.356 \\
3 & 45 & $13-17$ & 14.8 & $14.5-15.1$ & 0.975 \\
4 & 9 & $14-16$ & 15.0 & $14.3-15.7$ & 0.866 \\
5 & 17 & $14-16$ & 14.9 & $14.5-15.3$ & 0.749 \\
6 & 19 & $12-16$ & 14.3 & $13.7-14.9$ & 1.149 \\
7 & 25 & $13-18$ & 14.3 & $14.0-14.6$ & 0.781 \\
\hline
\end{tabular}


Figure 3. Modified Dice-Leraas symbols (Simpson et al., 1960) showing the variation in the length of the carapace of female G. xera. The horizontal line represents the observed range, the open rectangle shows the standard deviation and the solid black rectangle indicates the 95 per cent confidence interval for the mean. The mean is denoted by a vertical line and the number of specimens in each sample is given in parentheses. The numerical basis for these symbols is given in Table 1 . 
SAPSPLF

I

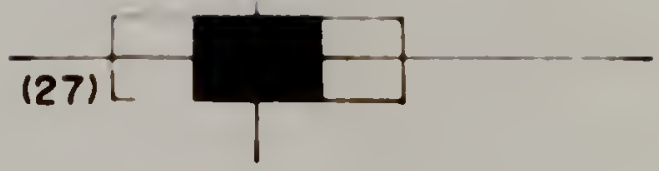

2

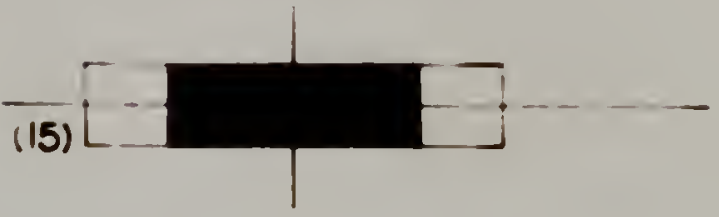

3

(45)

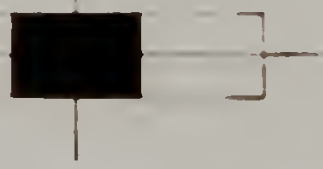

4

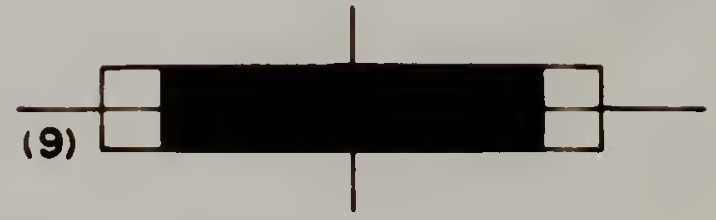

5

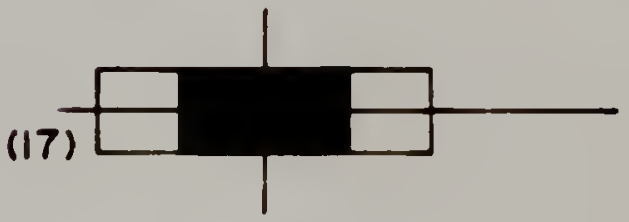

6

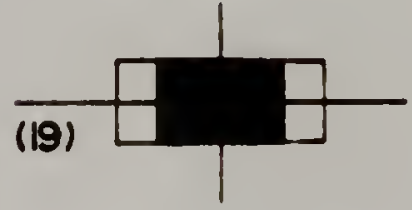

7
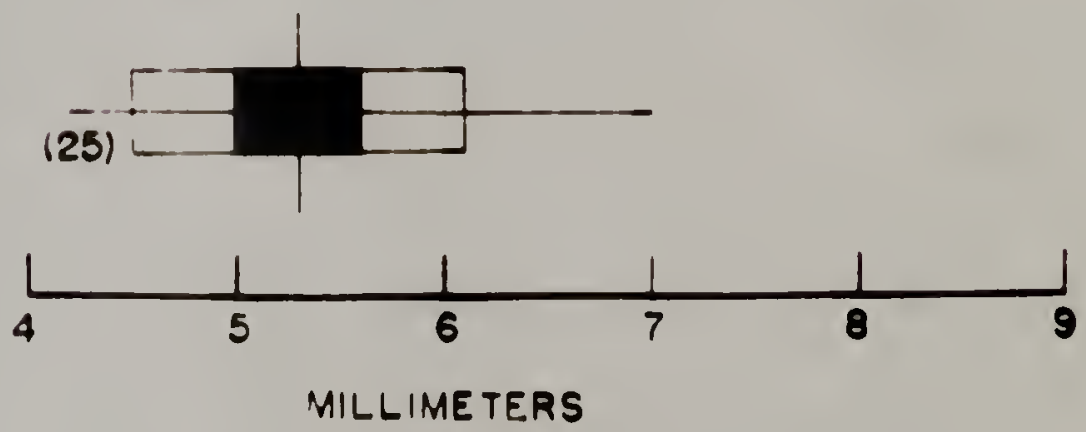
Figure 4. Symbols showing the variation in the length of the epigynum of female G. xera. For interpretation refer to Figure 3 . The numerical basis for these symbols is given in Table 2. 
SAMPLE

1

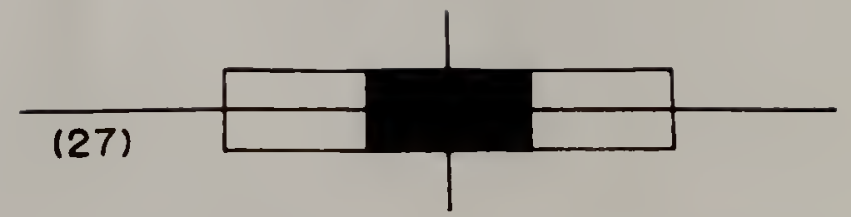

2

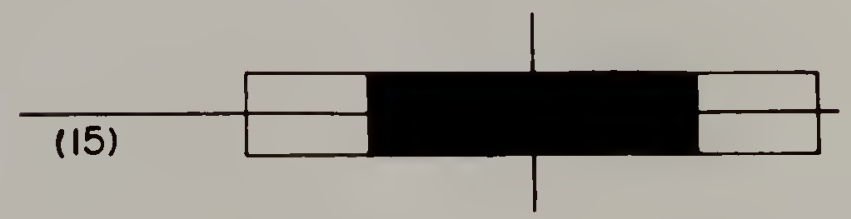

3

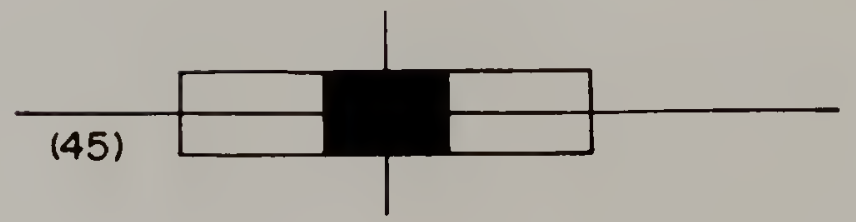

4

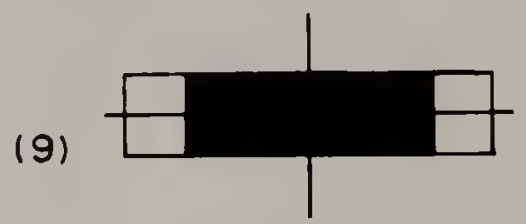

5
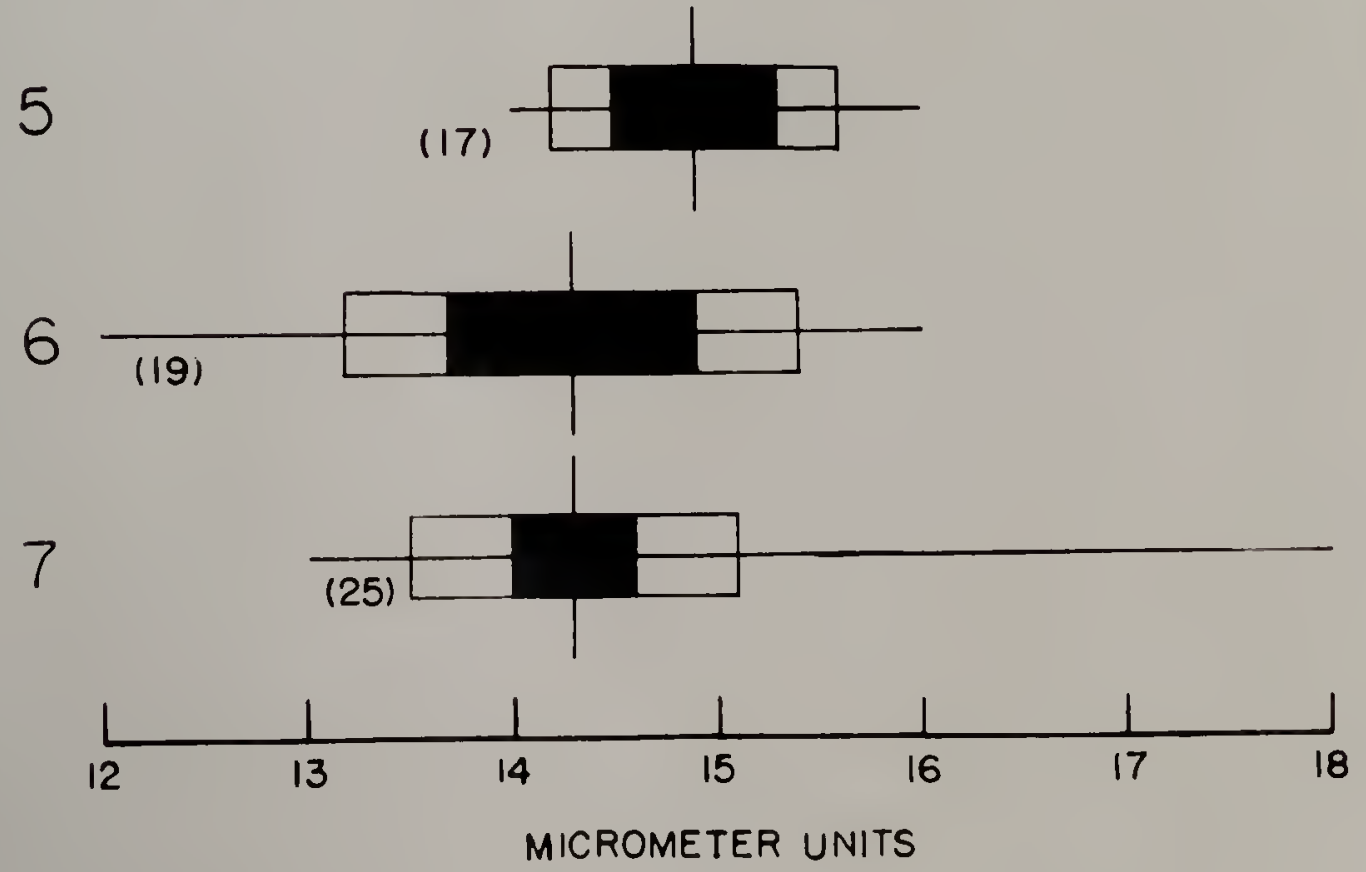
The most striking geographic variation involves the ventral color pattern. Black pigmentation is mostly restricted to legs $I$ and II. Occasionally the femur of $1 \mathrm{eg}$ III is dusky and a few of the specimens had black patellae on legs III and IV. Figure 5 shows the trend of variation in the pattern of black pigmentation on legs $I$ and II. It can be seen that there is a sharp break in pattern between samples 4 and 5 . This sharp break is surprising since both of these samples come from the town of Avon Park, and only two miles separate the two localities. The area lying between these localities was intensively searched, but no specimens were taken. Half of the specimens in sample 5 appear to be intermediate between those in samples 4 and 6 . A single specimen in sample 7 falls within the range of sample 3 . The discontinuity in the trend of variation of the ventral color pattern may be the result of one of two types of situations. First, samples 1-4 and 5-7 may represent two populations which were isolated from one another at one time. During this period of isolation, the two populations would have had an opportunity to independently evolve in response to the selection pressures in their respective environments. Later when they came into contact they could have been partially or completely reproductively isolated. A second possibility is that the abrupt change in color pattern may not represent a change from one to another genetically isolated population. Instead it may only be the result of an abrupt change from one type of environment or habitat to another. Thus this discontinuity does not necessarily indicate absence or reduction of gene flow between the two populations. 
Figure 5. Frequency distributions showing the variation in color pattern on the ventral surface of legs I and II in female $G$. xera. The digits above the bars denote the number of individuals in each class. 

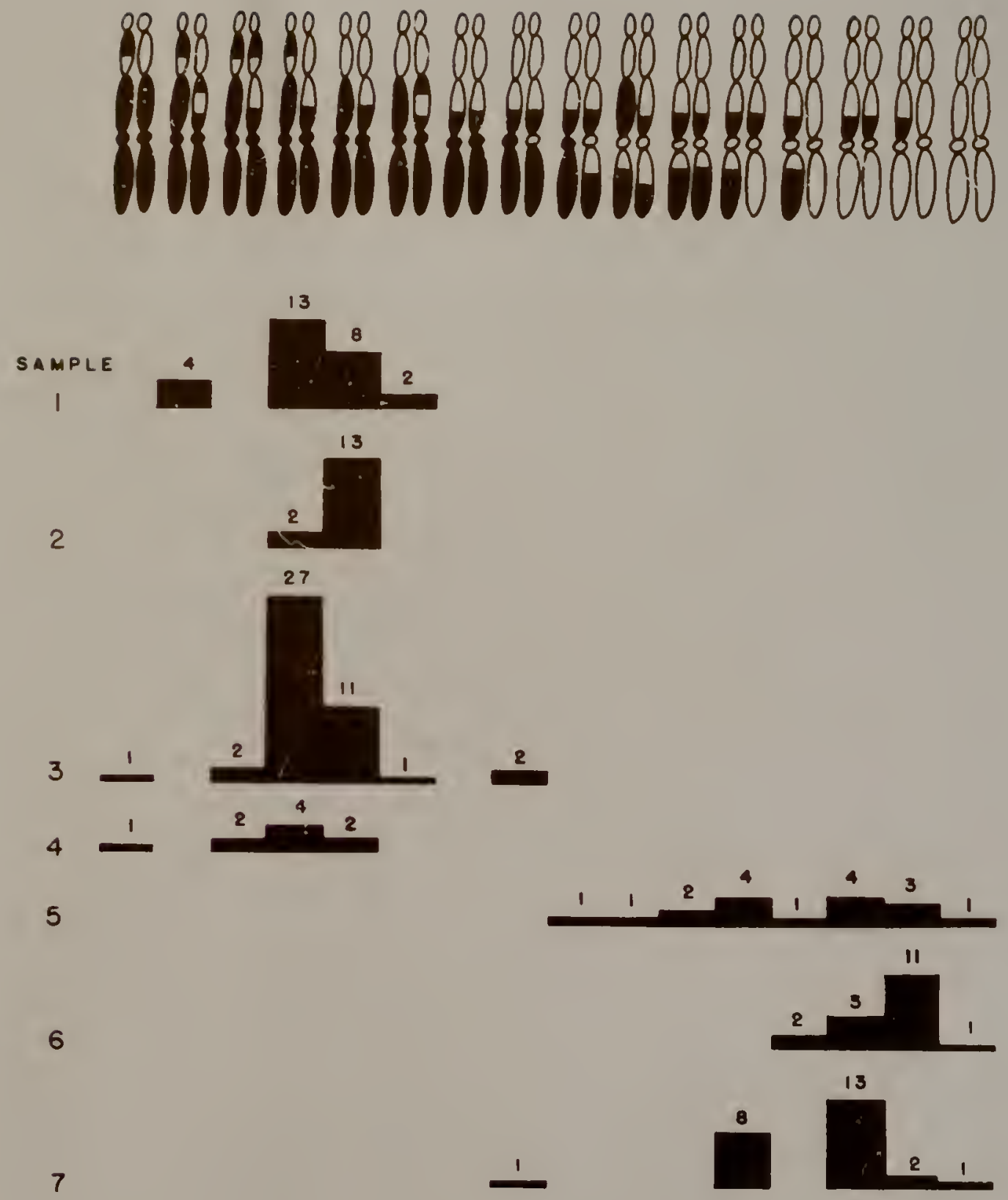
Such a sudden change in environment or habitat is not apparent in this area. The first situation seems more likely in view of the geological history of the area. The central part of each of the areas occupied by these two populations represents an old Pleistocene island. These islands were separated from each other for a period of approximately 200,000 years during the Aftonian Intergalcial stage, when strong currents of the Okefenokee Sea passed between them. This situation will be discussed more fully in the section of this paper dealing with the evolutionary history of the complex.

In the absence of genetic information, the taxonomic treatment of these two populations presents a difficult problem. Although the ventral color pattern on legs I and II provides almost 100 per cent separation of samples $1,2,3$ and 4 from samples 5,6 and 7 , the structure of the male and female genitalia is uniform throughout the range. The variation in the length of the female epigynum is clinal and does not allow for separation. In the discussion of species criteria, the importance of the degree of difference of the genitalia in determining specific status was stressed. Using this criterion it is apparent that the northern and southern populations must be included under one specific name. However, the variation in the ventral color pattern considered in conjunction with the geological history of the area would suggest that there is little gene flow between the two populations. Therefore, these two populations have been named as subspecies on the basis of the difference in the ventral color pattern on legs I and II. 
Geolycosa xera xera new subspecies

Remarks.-This is the nominate subspecies. A description of the holotype and allotype are given above.

Geographic Distribution.-Central Florida - South Volusia Co., Seminole $C_{0}$, , Orange $C_{0}$, , Lake Co., Polk Co, and northern Highlands Co. (Figure 14)

Records.-Florida: Highlands Co.: 4 miles east of Avon Park, Nov. 21, 1960, Cat. JMCC 66-1, road shoulders through scrub - 9 females. Lake Co.: 0.5 miles north of junction of State Road 561 and State Road 448 on 561, Dec. 30, 1959, Cat. McC 31, turkey oak - 6 females, 1 imm. Orange Co.: 5.5 miles south of Apopka on State Road 437, Dec. 30, 1959, Cat. JMCC 39, scrub - 2 females, 1 imm.; 2.7 miles south of Orlovista, Oct. 24, 1957, Cat. HKW 1923, scrub - 11 females, 1 imm.; $3.9 \mathrm{mi}$. Southeast of Apopka on U. S. 441, Mar. 1, 1939, Cat. HKW 1085, turkey oak - 1 female; 3.3 miles northwest of Apopka on U. S. 441, Mar. 2, 1939, Cat. HKW 1087, scrub - 1 female. Polk Co.: 8 mi. north of Avon Park on U. S. 27, Oct. 27, 1957, Cat. HKW 1939, scrub - 3 females; Dec. 31, 1959, Cat. JMcC 28, 11 females, imm.; Sept. 28, 1960, Cat. JMcC 62-3, 14 pen. males, 8 pen. females; Nov. 21, 1960, Cat. JMcC 65, 4 males, 25 females; junction of U. S. 27 and State Road 640, Dec. 31, 1959, Cat. JMcC 30, scrub - 4 females, imm.; $20.6 \mathrm{mi}$. south of Haines City on U. S. 27, Aug. 30, 1957, Cat. HKW 1913, scrub - 2 imm.; $17 \mathrm{mi}$. north of junction of U. S. 27 and U. S. 92 on 27, Dec. 30, 1959, Cat. JMcC 35, turkey oak - 5 females, 2 imm. Seminole Co.: Geneva, Dec. 30, 1959, Cat. JMCC 35, turkey oak - 2 females. Volusia Co.: 
$2.6 \mathrm{mi}$. east of 0steen, Dec. 29, 1959, Cat. JMcC 29, scrub - 8 females, imm.; Enterprise, Dec. 29, 1959, Cat. JMcC 36, scrub - 2 females; DeBary, Apr. 15,1960, Cat. McC 60-2, scrub - 4 females, 2 imm.; Sept. 28, 1960, Cat. MCC 62-2, 1 pen. male.

\section{Geolycosa xera archboldi new subspecies}

Holotype.-Male, from scrub at junction of State Road 70 and State Road 17, Highlands Co., Fla., Oct. 25, 1957, Cat. HKW 1928; allotype, a female with the same data: both will be deposited in the American Museum of Natural History, New York.

Description of Holotype.-In alcohol - Carapace uniform, no median stripe; covered with silvery pubescence; beneath pubescence central area near Windsor Tan; sides darker, near Burnt Sienna. Dorsum of abdomen covered with thick silvery pubescence, no markings; sides of abdomen black. Venter dusky. Sternum, coxae, endites and labium light; all segments of palpus 1ight. Proximal half of tibia $I$ and proximal third of tibia II black beneath; femora I-II dusky beneath; other segments light. Chelicerae near Burnt Sienna.

Carapace longer than wide $(5.4 \mathrm{~mm} . / 3.7 \mathrm{~mm}),. 2.3 \mathrm{~mm}$. high; width of head $2.6 \mathrm{~mm}$. Posterior eye quadrangle wider than long $(1.7 \mathrm{~mm} . / 1.3 \mathrm{~mm}$.$) , eyes of median row larger than those of posterior$ $(0.7 \mathrm{~mm} . / 9.5 \mathrm{~mm}$.$) ; median row wider than anterior row (1.3 \mathrm{~mm} . / 0.7 \mathrm{~mm}$.). Anterior row of eyes slightly procurved, eyes evenly spaced, medians larger than laterals $(0.3 \mathrm{~mm} . /) .2 \mathrm{~mm}$.$) . Distance from top of posterior$ median eyes to clypeus $1.3 \mathrm{~mm}$. Palpal segments: femur $2.0 \mathrm{~mm} .$, patella $0.6 \mathrm{~mm} .$, tibia $1.1 \mathrm{~mm}$., cymbium $1.6 \mathrm{~mm}$. Legs 4123 . 


\begin{tabular}{|c|c|c|c|c|c|c|}
\hline & Femur & Pate11a & Tibia & Metatorsus & Tarsus & Total \\
\hline I & 4.8 & 1.4 & 4.5 & 4.2 & 3.0 & 17.9 \\
\hline II & 4.2 & 1.4 & 3.9 & 4.2 & 3.0 & 16.7 \\
\hline III & 4.0 & 1.3 & 3.3 & 4.2 & 2.9 & 15.7 \\
\hline IV & 5.0 & 1.5 & 4.8 & 5.7 & 3.3 & 20.3 \\
\hline
\end{tabular}

Description of Allotype.-In alcohol - Carapace uniform, no median stripe; covered lightly with whitish-gray pubescence; near Orange Chrome bencath pubescence. Dorsum of abdomen uniform, no markings; color near Rose Beige; beset with numerous black bristles; anterior part of abdomen surrounding pedicel black. Venter dusky; beset with numerous black bristles. Sternum, endites and labium dusky; coxae light; femur of palpus dusky; all other segments light. Proximal third of tibia I and proximal fifth of tibia II black beneath; femur I dusky beneath; all other segments light. Chelicerae same color as carapace.

Carapace longer than wide $(6.0 \mathrm{~mm} . / 4.0 \mathrm{~mm}),. 2.5 \mathrm{~mm}$. high; width of head $3.2 \mathrm{~mm}$. Posterior eye quadrangle wider than long (2.0 mm./1.5 mm.), median eyes 1arger than laterals $(0.6 \mathrm{~mm} . / 0.5 \mathrm{~mm}$ ). posterior median eyes to clypeus $1.3 \mathrm{~mm}$. Palpal segments: femur $2.2 \mathrm{~mm}$. , patella $0.9 \mathrm{~mm} .$, tibia $1.2 \mathrm{~mm} .$, tarsus and claws $1.9 \mathrm{~mm}$. Distance from posterior edge of epigynum to anterior end of furrow of epigynum 0.6 mm. Legs 4123 .

\begin{tabular}{|c|c|c|c|c|c|}
\hline Femur & Patella & Tibia & Metatarsus & Tarsus & Total \\
\hline 4.1 & 1.7 & 3.3 & 3.0 & 2.2 & 14.3 \\
\hline 3.9 & 1.8 & 2.8 & 2.9 & 2.1 & 13.5 \\
\hline 3.5 & 1.2 & 2.2 & 2.6 & 2.2 & 11.7 \\
\hline 4.3 & 1.8 & 3.7 & 4.2 & 2.8 & 16.8 \\
\hline
\end{tabular}


Geographic Distribution.-Highlands Co.

Records.-Florida: Highlands Co.: $2 \mathrm{mi}$. south of Avon Park on U. S. 27, Nov. 21, 1960, Cat. JMcC 66-2, scrub - 2 males, 17 females, $2 \mathrm{imm} . ; 4.8 \mathrm{mi}$. south of junction of U. S. 27 and U. S. 98 on 27, Nov. 21, 1960, Cat. McC 66-3, scrub - 3 females; Oct. 27, 1957, Cat. HKW 1936, 11 females, 1 imm.; Archbold Biological Station, 0ct. 25, 1957, Cat. HKW 1927, scrub - 26 females, 2 imm.; junction of State Road 70 and State Road 17, Oct. 25, 1957, Cat. HKW 1928, scrub 1 male, 42 females, 3 pen. males, 13 imm.; Aug. 28, 1957, Cat. HKW 1907, 3 pen. males, 2 pen. females; $1.2 \mathrm{mi}$. west of junction of State Road 70 and State Road 17 on 70, Dec. 31, 1959, Cat. JMCC 32, scrub - 3 females; $6.1 \mathrm{ml}$. north of junction of U. S. 27 and State Road 621 on 27, Jan. 1, 1960, Cat. JMcC 33, scrub - 4 females; $9.5 \mathrm{mi}$. north of junction of U. S. 27 and State Road 621 on 27, Jan. 1, 1960, Cat. JMcC 40, mixed turkey oak and scrub - 8 females; $4 \mathrm{mi}$. southeast of Archbold Biological Station, Aug. 29, 1957, Cat. HKW 1912, scrub - 4 females, 5. pen. females, 5 pen. males; junction of U. S. 27 and U. S. 98, Oct. 27, 1957, Cat. HKW 1937, scrub - 4 females, 1 male; $10 \mathrm{mi}$. north of junction of U. S. 27 and U. S. 98 on 27, Oct. 27, 1957, Cat. HKW 1938, scrub - 5 females.

\section{Geolycosa patellonigra Wallace}

New Records.-Florida: Alachua Co.: $2 \mathrm{mi}$. west of Archer on State Road 24, Mar. 29, 1946, Cat. HKW 1179, sandy field in turkey oak 1 male, 8 females, 2 imm.; May 25, 1949, Cat. HKW 1316, 5 females, 3 pen. females; Dec. 7, 1958, Cat. JMcC 4, 2 females, 3 pen. males, 2 pen. 
females. Brevard Co.: $4 \mathrm{mi}$. north of Cocoa on U. S. 1, Feb. 5, 1960, Cat. JMCC 53, sandy field in scrub - 9 females, 1 pen. male (matured on Feb. 22, 1960); Mar. 20, 1961, Cat. JMcC 68, 2 females. Broward Co.: Fort Lauderdale, Feb. 4, 1960, Cat. JaC 50, scrub - 7 females, 1 pen. male. Citrus Co.: $3 \mathrm{mi}$. east of Holder on State Road 491, Oct. 18, 1957, Cat. HKW 1916, scrub - 2 females. Clay Co.: Lake Brook1yn, Dec. 13, 1958, Cat. JMcC 5, turkey oak - 4 females; Aug. 18, 1959, Cat. JMCC 23-1, 1 pen. male; Goldhead State Park, June 8, 1959, Cat. JMcC 18, turkey oak - 5 pen. females, 9 imm.; Nov. 15, 1960, Cat. MCC 64-2, 1 male; 15 females; $0.4 \mathrm{mi}$. west of Putnam - C1ay line on State Road 214, Aug. 18, 1959, Cat. JMcC 23-2, sandy field in turkey oak - 5 pen. males, 9 pen. females; Nov. 15, 1959, Cat. JMcC 26, 1 male, 11 females; Nov. 15, 1960, Cat. JMcC 64-1, 1 male, 10 females. Gilchrist Co.: 6.2 miles west of Newberry on State Road 26, Oct. 20, 1946, Cat. HKW 1236, turkey oak - 9 females, 2 pen. males, 5 pen. females, 2 imm.; Oct. 17, 1954, Cat. HKW 1856, 11 females, 4 pen. males, 5 imm.; Apr. 5, 1959, Cat. JMcC 15, 2 females, 10 imm.; July 8, 1959, Cat. JMcC 21, 1 pen. male, (matured Aug. 21, 1959), 1 pen. female; 0ct. 3, 1959, Cat. JMcC 24, 2 males, 12 females, 2 pen. males, 3 imm.; Mar. 19, 1960, Cat. $57-1,5$ females, $3 \mathrm{imm.;} 11 \mathrm{mi}$. north of Bell on State Road 129, Nov. 22, 1959, Cat. JMcC 27-2, road shoulders through turkey oak - 2 females. Hernando Co.: Weeki Wachee Springs, Mar. 23, 1947, Cat. HKW 1249, road shoulder through scrub - 7 imm.; Oct. 18, 1957, Cat. HKW 1919, 1 female, 3 imm.; Jan. 2, 1960, Cat. JMcC 38, 6 females, 3 pen. females; Sept. 28, 1960, Cat. 62-4, 8 females, 2 pen. males (both of these matured on Nov. 30, 1960); Apr. 11, 1961, Cat. JMcC 69-3, 7 
females ( 3 with young), 1 pen. male, 2 imm. Hillsborough Co.: 4 miles south of Boyette, June 20, 1959, Cat. JMcC 19-3, road shoulders through scrub - 6 females; Sept. 28, 1960, Cat. JMcC 62-5, 8 females ( 1 with egg sac); Apr. 11, 1961, Cat. JMcC 69, 5 females, 1 pen ma1e, 8 pen. females. Indian River Co.: $6 \mathrm{mi}$. south of Vero Beach on U. S. 1, Feb. 5, 1960, Cat. JMCC 54, scrub - 2 females, 1 pen. male (matured Feb. 17, 1960); $0.5 \mathrm{mi}$. north of Sebastian on U. S. 1, Mar. 20, 1961, Cat. JMcC 68 , scrub - 18 females ( 1 with young), 6 imm. Levy Co.: $5 \mathrm{mi}$. west of Archer on State Road 24, Mar. 2, 1946, Cat. HKW 1174, road shoulders through turkey oak - 5 females, 5 pen. males, 5 pen. females; Mar. 29, 1946, Cat. HKW 1180, 3 males, 30 females, 1 pen. male, 10 imm.; Apr. 8, 1951, Cat. HKW 1377, 2 females (1 with egg sac, 1 with young); Apr. 10, 1959, Cat. JMcC 17, 8 females, 4 pen. females, 2 imm.; $8 \mathrm{mi}$. west of Archer on State Road 24, Feb. 1, 1959, Cat. JMcC 8, turkey oak - 2 females, 2 pen. males, 1 pen. female, 5 imn.; Apr. 6, 1959, Cat. JMCC 16, 1 male, 3 females, 1 pen. female, 6 imm.; $8 \mathrm{mi}$. southwest of WilIiston on State Road 335, Apr. 4, 1959, Cat. JMCC 14, road shoulders and sandy field in turkey oak - 1 male, 10 females, 18 imm.; Oct. 18, 1959, Cat. JMcC 25, 4 males, 3 females. Marion Co.: $1 \mathrm{mi}$. east of Eureka on State Road 316, Mar. 21, 1959, Cat. JMcC 12-2, scrub - 3 pen. fema1es; $4 \mathrm{mi}$. east of Eureka on State Road 316, Mar. 21, 1959, Cat. JMCC 12-3, ecotone between scrub and turkey oak - 1 male, 1 female, 3 pen. females; Juniper Springs, Aug. 14, 1959, Cat. JMcC 22, road shoulder through scrub - 6 females ( 3 with young). Martin Co.: $4 \mathrm{mi}$. north of Jupiter on J. S. I, Feb. 4, 1960, Cat. JMcC 52, scrub - 1 female, 3 pen, males (1 matured Feb. 28, another Mar. 6), 2 pen. females. Palm 
Beach: De1ray Beach, Feb. 4, 1960, Cat. JMcC 51, scrub - 7 females, 3 pen. males, 1 pen. female. Pinellas Co.: St. Petersburg, Jan. 31, 1960, Cat. JMcC 46, scrub - 2 females, 2 pen. females. Putnam Co.: $21.4 \mathrm{mi}$. east of Gainesville on State Road 20, Mar. 3, 1946, Cat. HKW 1177, turkey oak - 2 males, 26 females, 9 imm.; 4 mi. north of Orange Springs on State Road 21, Mar. 8, 1959, Cat. JMC 11, turkey oak - 3 females, 6 imm.; Interlachen, Mar. 3, 1946, Cat. HKW 1178, ceratiola covered field - 3 females, 5 imm.; Oct. 23, 1954, Cat. HKW 1857, 3 females; Nov. 15, 1960, Cat. JMcC 63, 2 males, 10 females. St. Lucie Co.: Nigger Jim Scrub, Oct. 26, 1957, Cat. HKW 1930, scrub - 4 females. Sumter Co.: Sumterville, June 19, 1959, Cat. JMCC 19-1, road shoulders through turkey oak - 3 females, 2 pen. females; July 4, 1959, Cat. JMCC 20, 4 females ( 2 with young), 1 pen. male (matured July 15); Apr. 10, 1960, Cat. JMcC 59, 1 imm.; Apr. 11, 1961, Cat. JMcC 69, 7 females, 4 imm. Volusia Co.: DeLeon Springs, Dec. 29, 1959, Cat. JMCC 41, road shoulders through scrub - I female, 3 imm.; Apr. 15, 1960, Cat. JMCC 62, 8 females, 3 pen. males (1 matured Nov. 7); Daytona Beach Airport, Feb. 5, 1960, Cat. JMcC 55, scrub - 10 females, 2 pen. males (both matured Feb. 17), 1 imm.; Mar. 20, 1961, Cat. JMcC 68, 14 females (2 with young), $8 \mathrm{imm}$.

Geographic Distribution.-Florida - North Central, East Coast and West Coast (Figure 14).

Geographic Variation.-The method of analysis of the geographic variation in patellonigra is the same as that used for xera. Again the study is restricted to adult females. The structure and general conformation of the male and female genitalia is uniform throughout the 
range, but considerable geographic variation was found in the length of the carapace, length of the epigynum and various aspects of the ventral color pattern. The ventral color pattern and the length of the carapace of the males vary in the same manner as those of the females. Figure 6 show the areas from which the samples were taken.

Sample 1. Hillsborough Co.: 4 mi. S of Boyette (18).

Sample 2. Hernando Co.: Weeki Wachee Springs (19).

Sample 3. Sumter Co.: Sumterville (16).

Sample 4. Levy Co.: $6 \mathrm{mi}$. W of Archer on State Road 24 (13); $8 \mathrm{mi}$. W of Archer on State Road $24(10) ; 9 \mathrm{mi}$. W of Williston on State Road 335 (9). Alachua Co.s $2 \mathrm{ml}$. W of Archer on State Road 24 (2).

Sample 5. Gilchrist Co.: $6.2 \mathrm{mi}$. W of Newberry on State Road 26 (36); $11 \mathrm{mi} . \mathrm{N}$ of Bell on State Road 129 (2).

Sample 6. Clay Co.: Goldhead State Park (15).

Sample 7. Clay Co.: $0.4 \mathrm{ml}$. W of Putnam-Clay county line on $S 214$ (21).

Sample 8. Putnam Co.: Interlachen on State Road 20 (14).

Sample 9. Marion Co.: Ocala National Forest (32).

Sample 10. Volusia Co.: De Leon Springs (11).

Sample 11. Volusia Co.: Daytona Beach airport (22).

Sample 12. Brevard Co.: $4 \mathrm{mi} . \mathrm{N}$ of Cocoa on U. S. 1 (11).

Sample 13. Indian River Co.: $0.5 \mathrm{mi}$. N of Sebastian on D. S. 1 (17), $6 \mathrm{ml}$. S of Vero Beach on $0 . S .1$ (2).

Sample 14. Broward Co.: Ft. Lauderdale (6); Delray Beach (6).

Figure 7 illustrates the trend of variation in the length of 
Figure 6. Localities from which the samples of the various populations of $\mathrm{G}$. patellonigra were obtained. The outlined area represents the Eotal known distributional range. 


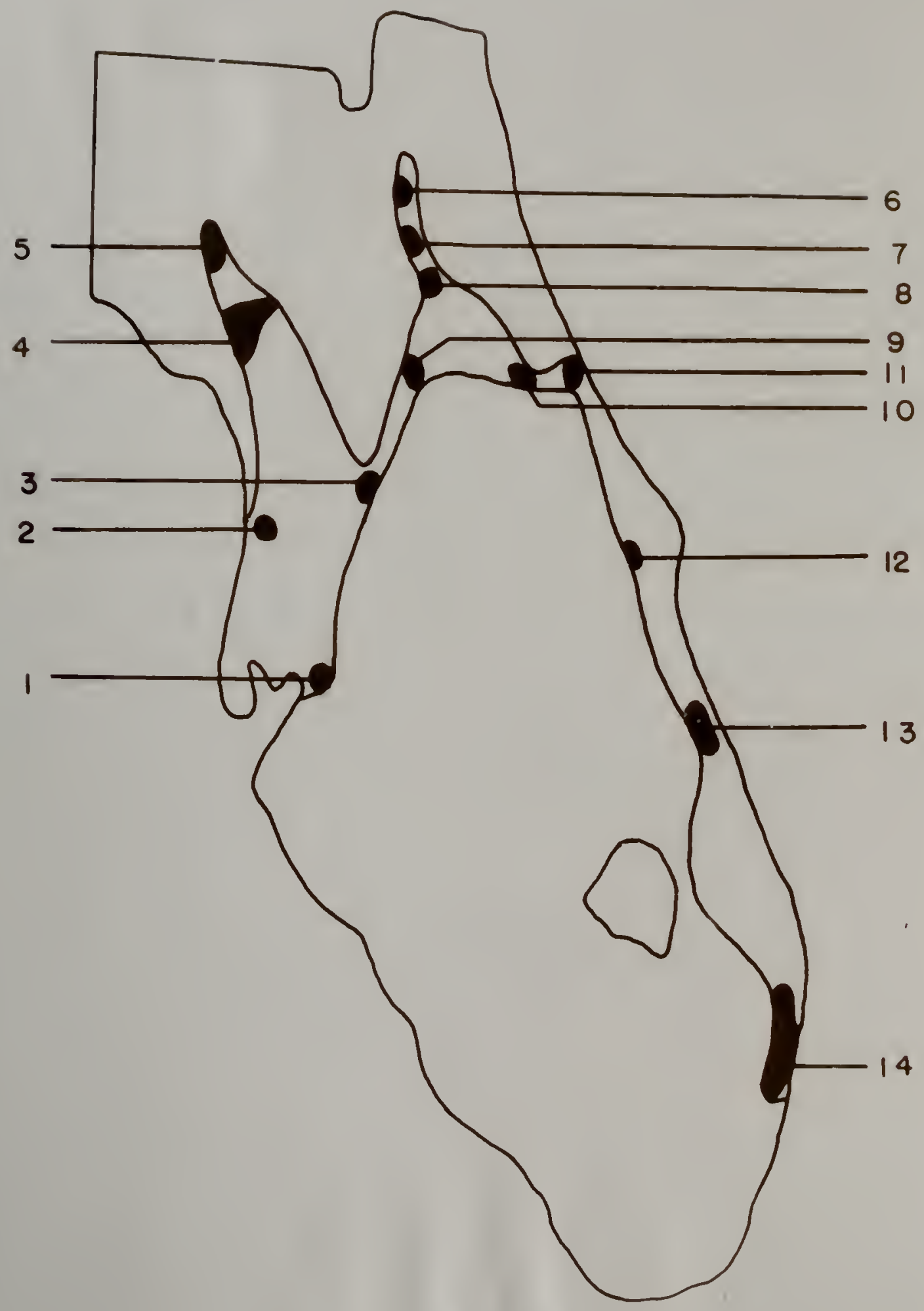


Figure 7. Symbols showing the variation in the length of the carapace of female G. patellonigra. For interpretation refer to Figure 3. The numerical basis for these symbols is given in Table 3. 
SAMPLE
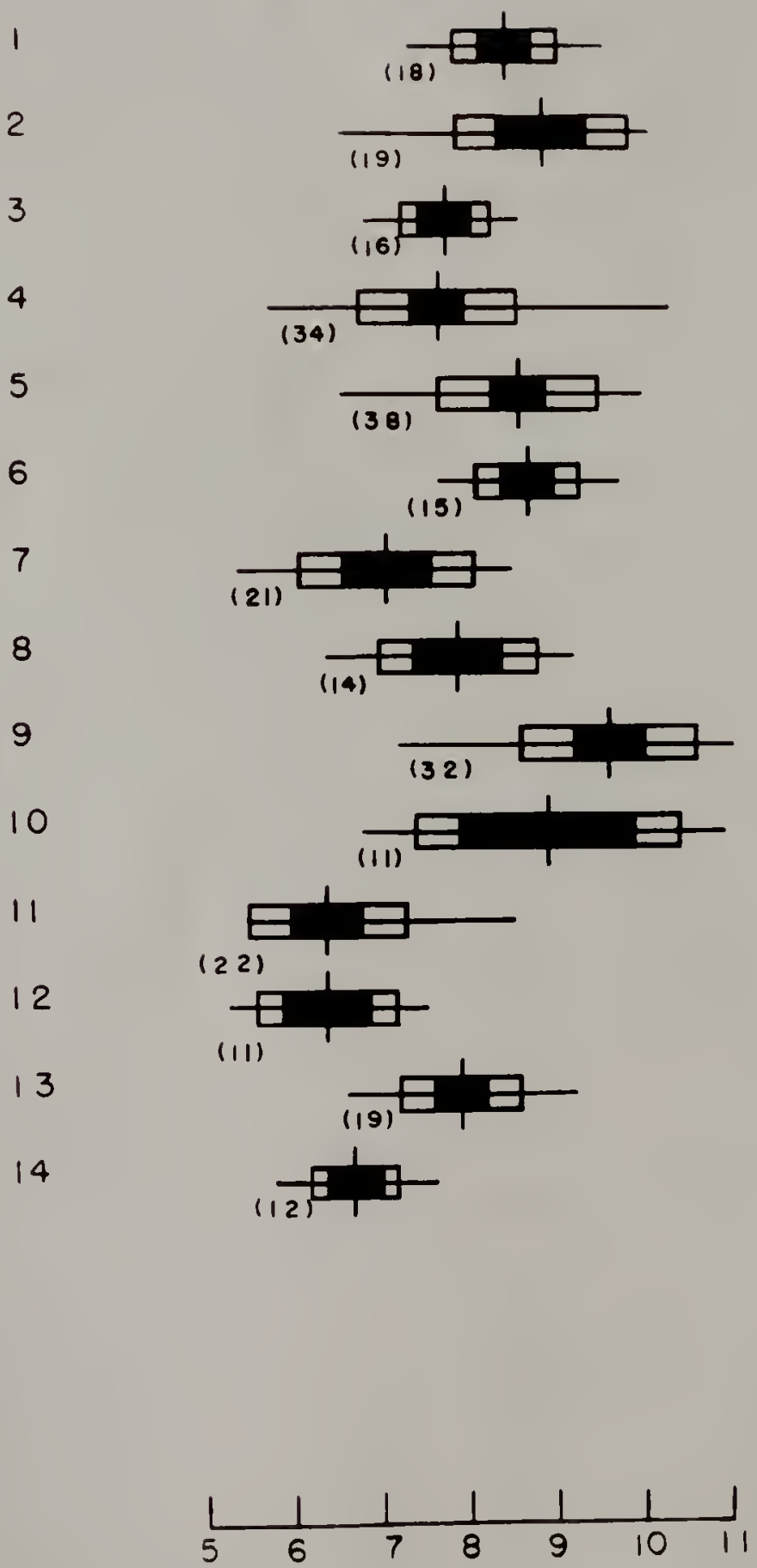

MILLIMETER S 
the carapace throughout the range. In many cases the interpopulation differences in carapace length are quite pronounced. For example, there is no overlap in the observed ranges of samples 6 and 14. However, there are no discernible clinal trends in this character, and the variation is chaotic.

Table 3.-Length of the carapace of female G. patellonigra

\begin{tabular}{cccccc}
\hline \hline $\begin{array}{c}\text { Sample } \\
\text { number }\end{array}$ & $\begin{array}{c}\text { Sample } \\
\text { size }\end{array}$ & Range & Mean & $\begin{array}{c}95 \% \text { Confidence } \\
\text { interval }\end{array}$ & S. D. \\
\hline 1 & 18 & $7.4-9.6$ & 8.5 & $8.2-8.8$ & 0.619 \\
2 & 19 & $6.6-10.1$ & 8.9 & $8.4-9.4$ & 0.074 \\
3 & 16 & $6.9-8.6$ & 7.8 & $7.5-8.1$ & 0.520 \\
4 & 34 & $5.8-10.3$ & 7.7 & $7.4-8.0$ & 0.939 \\
5 & 38 & $6.6-10.0$ & 8.6 & $8.3-8.9$ & 0.912 \\
6 & 15 & $7.7-9.7$ & 8.7 & $8.4-9.0$ & 0.612 \\
7 & 21 & $5.4-8.5$ & 7.1 & $6.6-7.6$ & 0.962 \\
8 & 14 & $6.4-9.2$ & 7.9 & $7.4-8.4$ & 0.865 \\
9 & 32 & $7.2-11.0$ & 9.6 & $9.2-10.0$ & 0.983 \\
10 & 11 & $6.8-10.9$ & 8.9 & $7.9-9.9$ & 1.453 \\
11 & 22 & $5.5-8.5$ & 6.4 & $6.0-6.8$ & 0.897 \\
12 & 11 & $5.3-7.5$ & 6.4 & $5.9-6.9$ & 0.758 \\
13 & 19 & $6.6-9.2$ & 7.9 & $7.6-8.2$ & 0.657 \\
14 & 12 & $5.8-7.6$ & 6.7 & $6.4-7.0$ & 0.523 \\
& & & & & \\
\hline
\end{tabular}

Figure 8 shows the trend of varlation in the length of the epigynum. There are no definite olinal trends, but with the exception of sample 2 the populations in the southern parts of the range tend to have shorter eplgyna. In xera, there was a close correlation between the trend of variation in the length of the carapace and the length of the epigynum. In patellonigra, no such correlation is evident. For example, the mean length of the carapace in samples 1 and 5 is similar, but the mean length of the eplgynum is very different. 
Figure 8. Symbols showing the variation in the length of the epigynum of female G. patellonigra. For interpretation refer to Figure 3. The numerical basis for these symbols is given in Table 4. 
SAMPLE

I

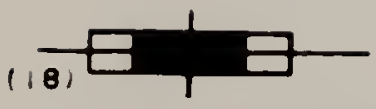

2

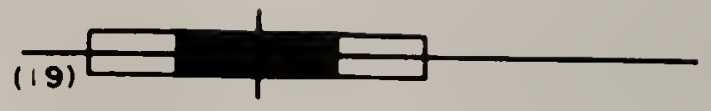

3

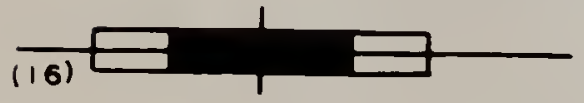

4

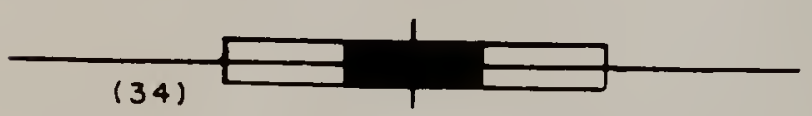

5

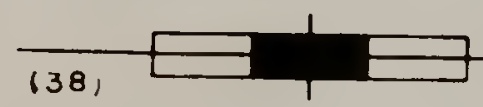

6

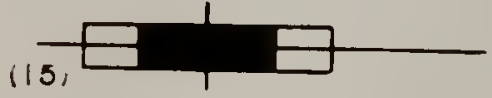

7

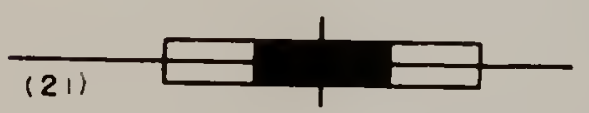

8

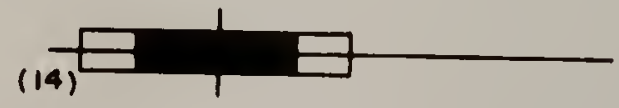

9

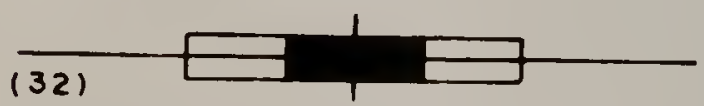

10

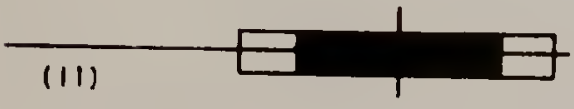

11

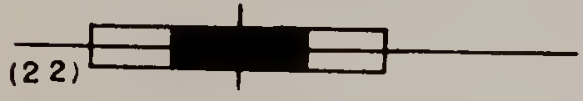

12

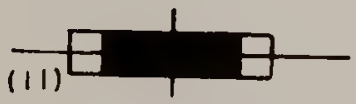

13

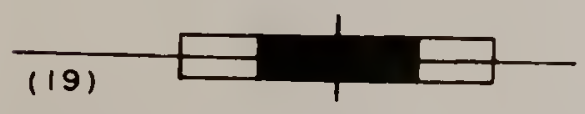

14
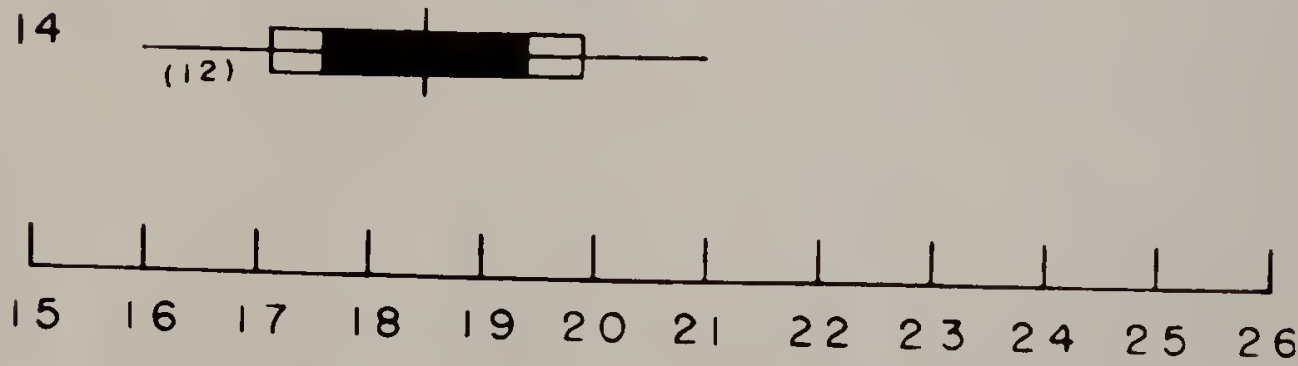

MICROMETER UNITS 
Table 4.-Length of the eplgynum of female G. patellonigra

\begin{tabular}{cccccc}
\hline $\begin{array}{c}\text { Sample } \\
\text { number }\end{array}$ & $\begin{array}{c}\text { Sample } \\
\text { size }\end{array}$ & Range & Mean & $\begin{array}{c}95 \% \text { Confidence } \\
\text { interval }\end{array}$ & S. D. \\
\hline 1 & 18 & $18-21$ & 19.4 & $18.9-19.9$ & 0.923 \\
2 & 19 & $20-26$ & 22.1 & $21.4-22.8$ & 1.487 \\
3 & 16 & $17-22$ & 19.2 & $18.4-20.0$ & 1.470 \\
4 & 34 & $17-24$ & 20.6 & $20.0-21.2$ & 1.689 \\
5 & 38 & $19-25$ & 21.6 & $21.1-22.1$ & 1.411 \\
6 & 15 & $20-24$ & 21.5 & $20.9-22.1$ & 1.127 \\
7 & 21 & $18-23$ & 20.8 & $20.2-21.4$ & 1.364 \\
8 & 14 & $20-25$ & 21.5 & $20.8-22.2$ & 1.225 \\
9 & 32 & $19-25$ & 22.0 & $21.4-22.6$ & 1.533 \\
10 & 11 & $17-22$ & 20.5 & $19.6-21.4$ & 1.371 \\
11 & 22 & $17-22$ & 19.0 & $18.4-19.6$ & 1.273 \\
12 & 11 & $18-21$ & 19.4 & $18.8-20.0$ & 0.925 \\
13 & 19 & $17-22$ & 19.9 & $19.2-20.6$ & 1.353 \\
14 & 12 & $16-21$ & 18.5 & $17.6-19.4$ & 1.382 \\
& & & & & \\
\end{tabular}

Patellonigra, 1ike xera, shows considerable variation in the ventral color pattern on legs I and II. Figure 9 iliustrates this variation. Samples 11-14 reveal that on the East Coast, from Daytona Beach south to Ft. Lauderdale, there is a clinal change in the distribution of black pigment on femora I and II. A similar cline on the West Coast would probably be demonstrated if specimens were available from the area lying between samples 1 and 2 . It is interesting that the ventral color pattern on legs I and II is identical in samples 1 and 14. Although these samples were taken at different latitudes, they both represent the southernmost, known population on each coast.

Samples 3 and 10 represent populations that have the closest contact with the range of xera. Sample 11 and 12 were also taken from areas that are spatially close to the range of xera, but the intervening terrain is ecologically unsuitable for both species. Both samples 3 
Figure 9. Frequency distributions showing the variation in color pattern on the ventral surface of legs I and II in female G. patellonigra. The digits above the bars denote the number of individuals in each class. 


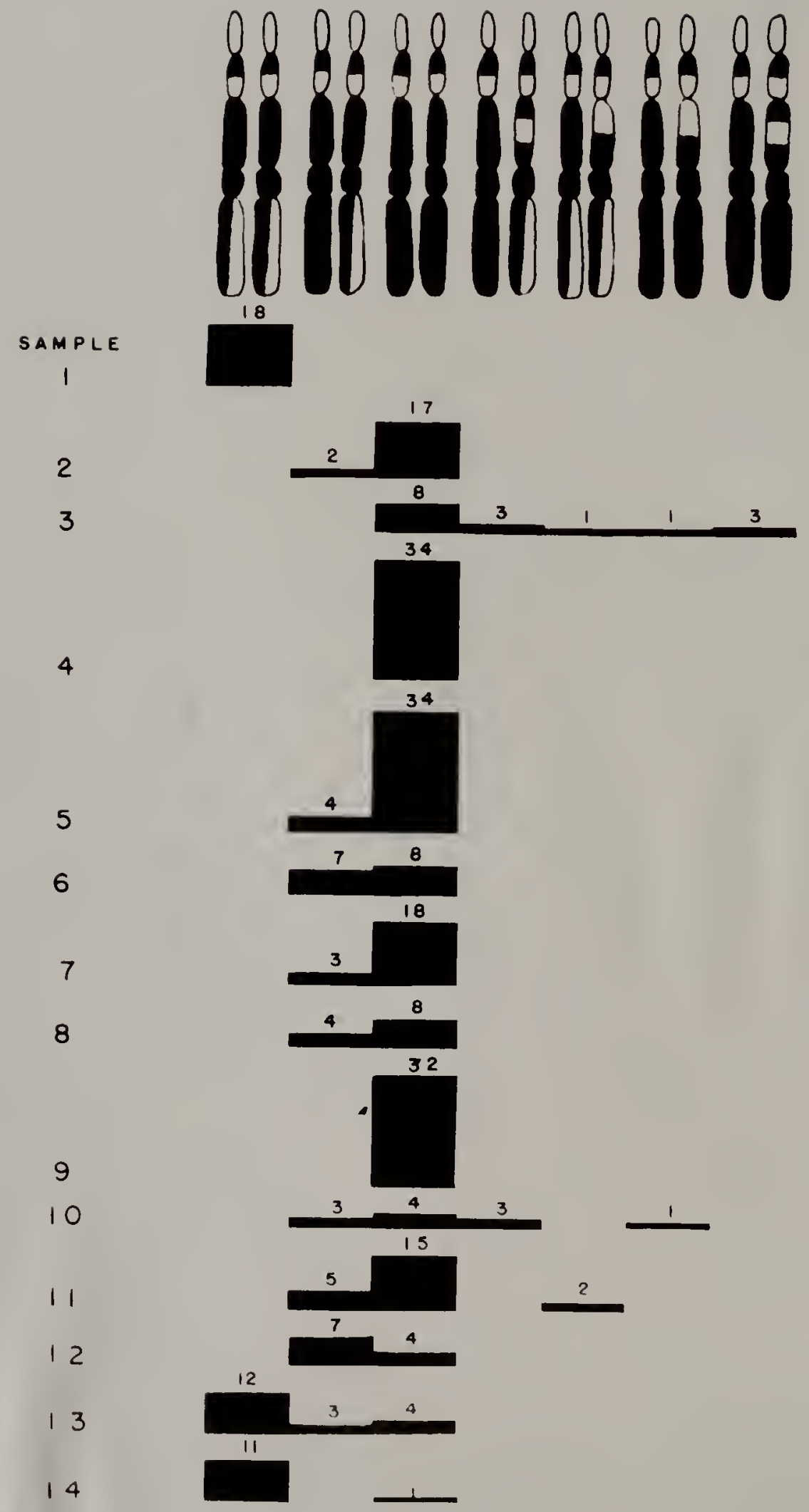


and 10 , show a greater variability in color pattern than the rest of the samples. This variability is in the direction of, but does not overlap the color patterns of the specimens of xera taken near these areas. This increased variability may be the result of secondary intergradation and the introgression of xera color pattern genes into patellonigra. The palpal organs of the few male specimens from these areas show the typical patellonigra type of structure.

As the name patellonigra 1mplies, most of the specimens have black plgmentation on the ventral surface of their patellae. However, some of the samples contained individuals with light patellae on legs III and IV. The percentage of individuals in each sample with light patellae is given in Table 5.

Table 5.-Percentage of female $G$. patellonigra with light patellae on legs III and IV.

\begin{tabular}{cccc}
\hline $\begin{array}{c}\text { Sample } \\
\text { number }\end{array}$ & $\begin{array}{c}\text { Sample } \\
\text { size }\end{array}$ & $\begin{array}{c}\text { Number of individuals } \\
\text { with light patellae }\end{array}$ & $\begin{array}{c}\text { Percentage of individuals } \\
\text { with light patellae }\end{array}$ \\
\hline 1 & 18 & 0 & 0 \\
2 & 19 & 0 & 0 \\
3 & 16 & 5 & 31 \\
4 & 34 & 0 & 0 \\
5 & 38 & 0 & 0 \\
6 & 15 & 5 & 33 \\
7 & 21 & 5 & 24 \\
8 & 14 & 5 & 36 \\
9 & 32 & 0 & 0 \\
10 & 11 & 5 & 45 \\
11 & 22 & 12 & 55 \\
12 & 11 & 4 & 36 \\
13 & 19 & 0 & 0 \\
14 & 12 & 2 & 17 \\
\hline
\end{tabular}

There is a clinal decrease in the frequency of this polymorphic character in all directions from the center of its distribution at 
Daytona Beach (Sample 11). This decrease does not appear to be correlated with any environmental gradlent.

The four characters discussed above show little or no concordance and do not provide a suitable basis for separating any of the populations taxonomically. 


\section{SEASONAL DISTRIBUTION}

\section{G. pikei}

Table 6 summarizes the available information on the seasonal distribution of the different stages of development. Most of these data were taken from Emerton (1912) and Wallace (1942).

Table 6.-Observed seasonal population composition of $\underline{G}$. pikei

\begin{tabular}{|c|c|c|c|c|c|c|c|c|c|c|c|}
\hline \multirow[b]{2}{*}{ Stage of development } & \multirow[b]{2}{*}{$F$} & \multirow[b]{2}{*}{$M$} & \multirow[b]{2}{*}{$A$} & \multirow[b]{2}{*}{$M$} & \multicolumn{3}{|c|}{ Month" } & \multirow[b]{2}{*}{ S } & \multirow[b]{2}{*}{0} & \multirow[b]{2}{*}{$\mathrm{N}$} & \multirow[b]{2}{*}{$\mathrm{D}$} \\
\hline & & & & & $\mathrm{J}$ & $J$ & $A$ & & & & \\
\hline Adult males & & & & & & & $X$ & $X$ & & & \\
\hline Adult females & $\mathrm{X}$ & $\mathbf{X}$ & $X$ & $\mathrm{X}$ & $\mathrm{X}$ & $\mathrm{X}$ & $\mathrm{X}$ & $\mathrm{X}$ & $\mathbf{X}$ & $\mathrm{X}$ & $\mathrm{X}$ \\
\hline Penultimate males & & & & & $\mathrm{X}$ & $X$ & $\mathrm{X}$ & & & & \\
\hline Penultimate females & & & & & $X$ & $\mathrm{X}$ & $\mathrm{X}$ & & & & \\
\hline Immatures & $\mathrm{X}$ & $\mathrm{X}$ & $\mathrm{X}$ & $\mathrm{X}$ & $\mathrm{X}$ & $\mathrm{X}$ & $X$ & $X$ & $\mathbf{X}$ & $\mathrm{X}$ & $X$ \\
\hline Females with egg sacs & & & & $X$ & $\mathrm{X}$ & & & & & & \\
\hline Females with young & & & & & $X$ & $X$ & & & & & \\
\hline
\end{tabular}

*No data are available for January.

Penultimate males and females appear in June. These mature and mate in August and September. The adult males have completed their life span by october, but the females overwinter and lay their eggs in May and early June. Females with young are found in late June and July. These young represent the immatures found during August and September. Thus the males and females which mature and mate during this period were hatched the preceding year. This two-year cycle appears to be typical of many species of Geolycosa. Although it takes two years for the life cycle to be completed, males and females mature and mate every year. 


\section{G. xera}

Table 7 summarizes the available information on the seasonal distribution of the different stages of development.

Table 7.-Observed seasonal population composition of $\underline{G}$. xera

\begin{tabular}{|c|c|c|c|c|c|c|c|c|c|c|c|c|}
\hline \multirow[b]{2}{*}{ Stage of development } & \multicolumn{11}{|c|}{ Month } & \multirow[b]{2}{*}{$\mathrm{D}$} \\
\hline & $J$ & $F$ & M & $A$ & $\mathrm{M}$ & $\mathrm{J}$ & $\mathrm{J}$ & $A$ & $S$ & 0 & $\mathrm{~N}$ & \\
\hline Adult males & & & & & & & & & & $\mathrm{X}$ & $\mathrm{X}$ & \\
\hline AduIt females & $\mathrm{x}$ & $\mathrm{X}$ & $\mathrm{X}$ & $\mathrm{X}$ & $\mathrm{X}$ & $\mathrm{x}$ & $\mathrm{X}$ & $\mathrm{X}$ & & $\mathrm{x}$ & $\mathrm{X}$ & $\mathrm{X}$ \\
\hline Penultimate males & & & & & & $\mathrm{x}$ & $\mathrm{X}$ & $\mathrm{X}$ & $\mathrm{x}$ & $X$ & & \\
\hline Penultimate females & & & & & & $\mathrm{x}$ & $\mathrm{X}$ & $\mathrm{X}$ & $\mathrm{X}$ & & & \\
\hline Immatures & $\mathrm{x}$ & $\mathrm{X}$ & $\mathrm{X}$ & $\mathrm{x}$ & $X$ & $\mathrm{X}$ & $\mathrm{X}$ & $\mathrm{X}$ & $\mathrm{X}$ & $\mathrm{x}$ & $\mathrm{X}$ & $\mathrm{X}$ \\
\hline Females with egg sacs & & & $\mathrm{X}$ & & & & & & & & & \\
\hline Females with young & & & & $\mathrm{X}$ & & & & & & & & \\
\hline
\end{tabular}

Penultimate males and females appear every year in June. These mature and mate in october and November. The adult males have completed their Iife span by December, but the females overwinter and lay their eggs in March. Females with young are found in April. These young are still immature during the following October and November, therefore, the males and females which mature during this period were hatched the preceding year. This is a two-year cycle similar to that of pikei, however, xera matures and mates later in the fall and its eggs are laid earlier in the spring. The fact that xera lives in a warmer climate probably accounts for these differences.

$$
\text { G. pate11onigra }
$$

A consideration of the seasonal distribution of patellonigra revealed a very different situation from that encountered in pikei and 
xera which have a single breeding period during the fall of each year. A1though all of the populations of patellonigra follow the typical twoyear cycle, the seasonal occurrence of the breeding period varies geographically, and in some areas there are two breeding seasons a year.

Table 8 summarizes the available information on the seasonal distribution of the different stages of development in the populations inhabiting Gilchrist, Clay, Putnam and western Volusia counties.

Table 8. -Observed seasonal population composition of $\mathbf{G}$. patellonigra in Gilchrist, Clay, Putnam and western Volusia counties.

\begin{tabular}{|c|c|c|c|c|c|c|c|c|c|c|c|c|}
\hline \multirow[b]{2}{*}{ Stage of development } & \multicolumn{12}{|c|}{ Month } \\
\hline & $\mathbf{J}$ & $F$ & M & A & $M$ & $\mathrm{~J}$ & $\mathrm{~J}$ & A & $\mathrm{S}$ & 0 & N & $\mathrm{D}$ \\
\hline Adult males & & & & & & & & & & $\mathrm{X}$ & $\mathrm{X}$ & \\
\hline Adult females & $\mathbf{X}$ & $\mathrm{X}$ & $\mathrm{X}$ & $\mathrm{X}$ & $X$ & $\mathrm{X}$ & & & $\mathrm{X}$ & $\mathrm{X}$ & $X$ & $X$ \\
\hline Penultimate males & & & & & & $\mathrm{X}$ & $\mathrm{X}$ & $\mathrm{X}$ & $\mathrm{X}$ & $\mathrm{X}$ & & \\
\hline Penultimate females & & & & & & $\mathrm{X}$ & $\mathrm{X}$ & $\mathrm{X}$ & $\mathrm{X}$ & $\mathrm{X}$ & & \\
\hline Immatures & $\mathrm{X}$ & $\mathrm{X}$ & $\mathrm{X}$ & $\mathrm{X}$ & $\mathrm{X}$ & $\mathrm{X}$ & $\mathrm{X}$ & $\mathrm{X}$ & $\mathrm{X}$ & $\mathrm{X}$ & $\mathrm{X}$ & $\mathrm{X}$ \\
\hline Females with egg sacs & & & & $\mathrm{X}$ & & & & & & & & \\
\hline Females with young & & & & $\mathrm{X}$ & & & & & & & & \\
\hline
\end{tabular}

This life cycle is similar to that of pikei and identical to that of xera.

The data for the populations inhabiting Marion and Hillsborough counties are given in Table 9. In these counties the males and females mature and mate in May instead of in the fall. Females with young are found from August to October.

The populations in Levy, Alachua, Hernando and Sumter counties have two breeding seasons a year (Tab1e 10), one in March and Apri1, the other in october. 
Table 9.-Observed seasonal population composition of G. patellonigra in Marion and Hillsborough counties.

\begin{tabular}{|c|c|c|c|c|c|c|c|c|c|}
\hline \multirow[b]{2}{*}{ Stage of development } & \multirow[b]{2}{*}{$F$} & \multicolumn{8}{|c|}{ Month" } \\
\hline & & M & A & M & $\mathrm{J}$ & $\mathrm{J}$ & A & $\mathrm{S}$ & 0 \\
\hline Adult male & & & & $\mathrm{x}$ & & & & & \\
\hline Adult female & $\mathrm{X}$ & $\mathrm{x}$ & $\mathrm{x}$ & $\mathrm{x}$ & $\mathrm{X}$ & $\mathrm{X}$ & $\mathrm{X}$ & $\mathrm{X}$ & $\mathrm{x}$ \\
\hline Penultimate male & & $\mathrm{x}$ & $\mathrm{x}$ & $\mathrm{x}$ & & & & & \\
\hline Penultimate female & & $\mathrm{x}$ & $\mathrm{X}$ & $\mathrm{x}$ & & & & & \\
\hline Immatures & $\mathrm{X}$ & $\mathrm{x}$ & $x$ & $\mathrm{x}$ & $\mathrm{x}$ & $\mathrm{X}$ & $\mathrm{X}$ & $\mathrm{x}$ & $\mathrm{x}$ \\
\hline Females with egg sac & & & & & & & & & \\
\hline Females with young & & & & & & & $\mathrm{x}$ & $\mathrm{x}$ & $\mathrm{X}$ \\
\hline
\end{tabular}

* No data are available for November through January.

The females with young in April probably represent those females which mated the previous fall, while those in July represent females which mated in the spring.

Information on the seasonal distribution of the different stages of development in the populations on the East Coast is not as complete as that for other areas. Data from eastern Volusia, Brevard and Indian River counties are available only for February, March and April. These are given in Table 11.

The fact that females with young are found in March, the month following the breeding season, would indicate that these populations breed twice in a year. In all the other populations of patellonigra, and in xera and pikei, females are not found with young until at least three months after the breeding period. Therefore, the females with young found in March probably mated the preceding fall.

Farther down the coast in Martin, Palm Beach and Broward counties, adult males and females, penultimate males and females and immatures have been found in February. No data are available for the 
other months so it is impossible at this time to say whether the populations in these counties have a single or double breeding season.

Table 10.-Observed seasonal population composition of G. patellonigra in Levy, Alachua, Hernando and Sumter counties.

\begin{tabular}{|c|c|c|c|c|c|c|c|c|c|c|c|c|}
\hline \multirow[b]{2}{*}{ Stage of development } & \multirow[b]{2}{*}{$\mathrm{J}$} & \multirow[b]{2}{*}{$F$} & \multirow[b]{2}{*}{ M } & \multirow[b]{2}{*}{$A$} & \multicolumn{3}{|c|}{ Month } & \multirow[b]{2}{*}{ A } & \multirow[b]{2}{*}{$\mathrm{S}$} & \multirow[b]{2}{*}{0} & \multirow[b]{2}{*}{$\mathrm{N}$} & \multirow[b]{2}{*}{$\mathrm{D}$} \\
\hline & & & & & M & $J$ & $\mathrm{~J}$ & & & & & \\
\hline Adult males & & & $\mathrm{X}$ & $\mathrm{X}$ & & & & & & $\mathrm{X}$ & & \\
\hline Adult females & $X$ & $X$ & $X$ & $X$ & $X$ & $\mathrm{X}$ & $\mathrm{X}$ & $\mathrm{X}$ & $\mathrm{X}$ & $\mathrm{X}$ & $\mathrm{X}$ & $\mathrm{X}$ \\
\hline Penultimate males & $X$ & $X$ & $X$ & $X$ & & $X$ & $X$ & $\mathrm{X}$ & $X$ & $\mathrm{X}$ & & $X$ \\
\hline Penultimate females & $X$ & $X$ & $\mathrm{X}$ & $\mathrm{X}$ & & $\mathrm{X}$ & $X$ & $\mathrm{X}$ & $X$ & $\mathrm{X}$ & & $X$ \\
\hline Immatures & $\mathrm{X}$ & $X$ & $\mathrm{X}$ & $\mathrm{X}$ & $\mathrm{X}$ & $\mathrm{X}$ & $\mathrm{X}$ & $\mathrm{X}$ & $\mathrm{X}$ & $\mathrm{X}$ & $\mathrm{X}$ & $\mathrm{X}$ \\
\hline Female with egg sacs & & & & $X$ & & & & & & & & \\
\hline Females with young & & & & $\mathrm{X}$ & & & $\mathrm{X}$ & & & & & \\
\hline
\end{tabular}

Figure 10 shows the geographic distribution of the various breeding seasons throughout the range of patellonigra. With the exception of the population in Marion County, there is a change from strictly fall breeders to fall and spring breeders as you go south. On the West Coast this change is completed in Hillsborough County where the population is strictly a spring breeder. A similar situation may be encountered on the East Coast when more data are available from the southern portion.

Geographic variation in non-morphological character, such as time of breeding, are important factors in the process of speciation yet are difficult to evaluate because of the paucity of information on their genetic basis (Mayr, 1942). The timing of the breeding season in the various populations studied above appears to be under genetic control. The fact that the population in Marion County is strictly a spring breeder, 
Figure 10. Geographic variation in breeding season in G. pate1lonigra. 


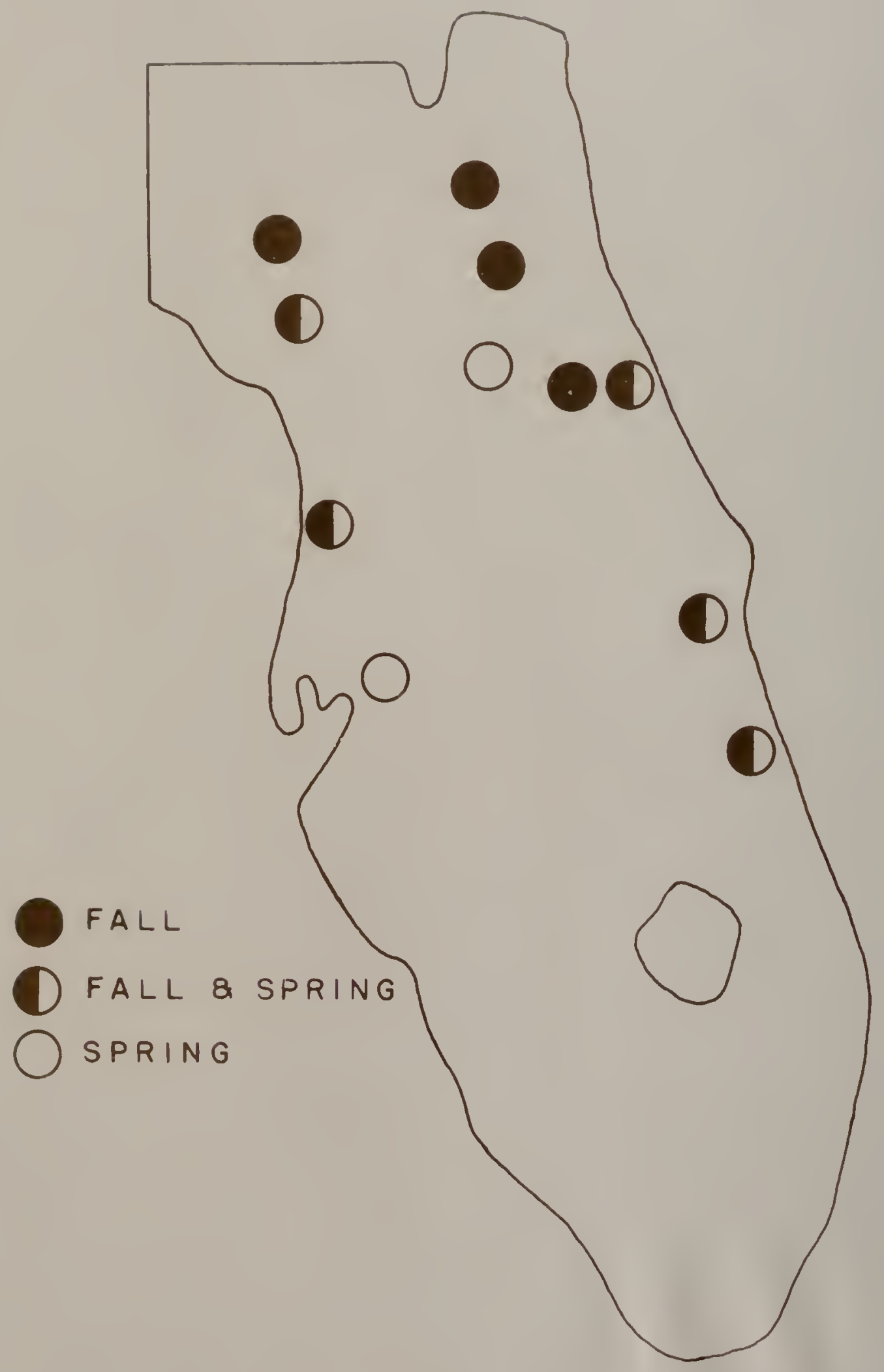


in spite of its relatively northern location, would seem to preclude the possibility that the breeding periodicity is strictly an ontogenetic response to some north-south environmental gradient such as temperature.

An attempt was made to correlate the geographic differences in breeding season with the geographic variation of the morphological characters, but no definite correlations could be established.

Table 11.-Observed seasonal population composition of G. patellonigra in western Volusia, Brevard

\begin{tabular}{|c|c|c|c|}
\hline \multirow{2}{*}{ Stage of development } & \multicolumn{3}{|c|}{ Month } \\
\hline & $\mathrm{F}$ & & A \\
\hline Adult males & $\mathrm{x}$ & & \\
\hline Adult females & $\mathrm{x}$ & $\mathrm{X}$ & $\mathrm{x}$ \\
\hline Penultimate males & $\mathrm{x}$ & & \\
\hline Penultimate females & $\mathrm{x}$ & & \\
\hline Immatures & $\mathrm{x}$ & $\mathrm{x}$ & $\mathrm{X}$ \\
\hline Females with egg sacs & & $X$ & \\
\hline Females with young & & $\mathrm{X}$ & \\
\hline
\end{tabular}

* No data available for May through January.

\section{Discussion}

In xera and all the populations of patellonigra which have a single breeding season, a curious situation is encountered. Although it takes two years for the life cycle to be completed, males and females mature and mate every year. Since the females which mature in an even year have completed their life span before the males of the next, or odd, year have matured, it would appear that populations which mature in even and odd years are reproductively isolated. This 
annual isolation within the same geographic and habitat area could provide a possible method for sympatric speciation. Such annual isolation has been considered to be a rare phenomenon (Emerson, 1949). However, Gabbutt (1959) has recently described a comparable situation in some English populations of the wood cricket, Nemobius sylvestris (Bosc.). He found that the crickets in these populations had a two-year life cycle, and there was no evidence indicating overlap of the populations which matured in even and odd years.

If the populations which mature in even and odd years are reproductively isolated, as they appear to be, it might be possible to detect some morphological differences. In order to check this, a comparison was made between two samples taken from a population in Clay County which breeds only in the fall. One sample was collected on Nov. 15, 1959, while the other was collected the following year on the same date. Each sample consisted of ten females and one male. No differences were found in the ventral color pattern or the structure of the genitalia, and no statistically significant differences could be demonstrated in the length of the carapace and epigynum. Differences may have been present and gone undetected since the samples were sma11. A1so both populations are living in the same area and are presumably responding to similar selection pressures.

In pikei and the populations of patellonigra with two breeding seasons, females are present all year round so there is at least a chance for gene flow between the populations which mature in the even and odd years. It is of course possible that the females of 
these populations can only be fertilized for a short period after they mature. If this is the case, then the situation would become exceedingly complex. In addition to an annual 1solation, there would be a superimposed, seasonal isolation in the populations with two breeding seasons making four reproductively isolated populations. Alexander and Bigelow (1960) have proposed that such a seasonal type of isolation has provided the basis for the sympatric speciation of two closelyrelated species of field crickets, Acheta pennsylvanicus and A. veletis. 


\section{POST-PLIOCENE HISTORY OF THE SOUTHEASTERN COASTAL PLADN}

A brief summary of the general aspects of the Post-Pliocene history of the lower southeastern Coastal Plain is necessary before considering the present distribution, habitat relations and evolutionary history of the plkei complex. The following account is based on information obtained from the publications of Cooke (1945), MacNeil (1950), Fint (1957) and Laessle (1958).

During the P1iocene Florida was a peninsula. With the advent of the first glaciation of the Pleistocene, the Nebraskan, there was a drop in sea level, and this peninsula was considerably enlarged. The subsequent Aftonian Interglacial raised the sea level again, and large parts of Florida and Georgia were inundated. The 150-ft. Okefenokee shoreline was formed at this time. Several islands and island groups remained above the level of the Okefenokee Sea. Figure 11 show the location of this 150-ft. shoreline and the islands of the Okefenokee Sea.

There were three prominent island groups, one in North Central Florida grouped about Trail Ridge, one just north of Tampa Bay and one grouped around the Lake Wales Ridge. On his map of the Pleistocene shorelines of Flonida and Georgia MacNeil (1950) showed a small isolated island just south of the Lake Wales Ridge as being the southernmost island of the Okefenokee Sea. However, Laessle (1958) provided information which confirmed the existence of another island, Red Hill, about 30 or 35 miles further south. Strong currents of the Okefenokee Sea 
Figure 11. The approximate land areas of the Okefenokee Sea superimposed on the present shore line of Florida and Georgia. This map is a modification of that of MacNeil (1950). The arrows show the direction of the stronger currents. 


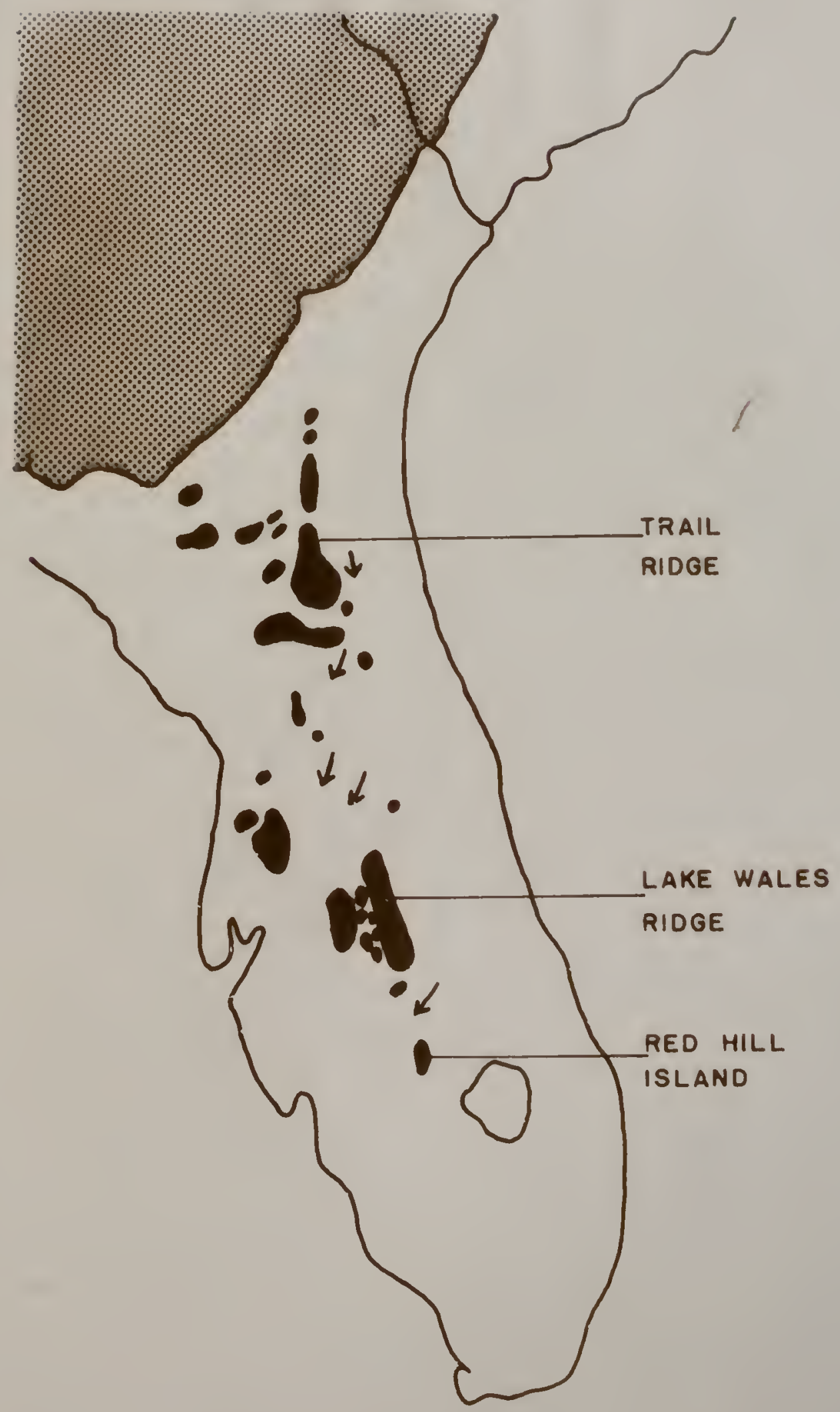


passed south and east of the Trail RIdge and Tampa Bay island groups and separated them from the Lake Wales Ridge group. Other strong currents passed between the latter group and Red H1II Island.

The next glaclal period, the Kansan, was accompanied by another drop in sea level. The rise in sea level during the following Yarmouth Interglacial was not as great as that in the Aftonian, and a new shoreline, the H1comico, formed at the 100-ft. leve1. Figure 12 shows the location and extent of the early Hicomico 1slands. The area occupied by the Trail Ridge Island group in the Okefenokee sea was now connected to the malnland, but there was st111 a large island in the central part of Florida. Red Hill island was connected to this central island. The strong currents of the Wicomico sea passed between the mainland and the large central island.

During the Sangamon Interglacial which followed the next glaciation, the Illinolan, the 25 to $30-\mathrm{ft}$. Paml1co shoreline was formed. Figure 13 shows the shoreline. Most of Florida was a penInsula, but there was a chain of islands down the East and Fest Coasts. The final shoreline before the Recent was the 8 to 10-ft. Silver Bluff. This is of Post-Wisconsin origin.

The various Post-P1locene Interglacial stages and their associated shorelines are summarized in Table 12. Also the estimated duration of each of the Interglacials is given. These estimates were taken from Kay (1931). 
Figure 12. The approximate land areas of the ear1y Wicomico Sea superimposed on the present shorelines of Florida and Georgia. This map is a modification of that of MacNeil. The arrows show the direction of the stronger currents. 


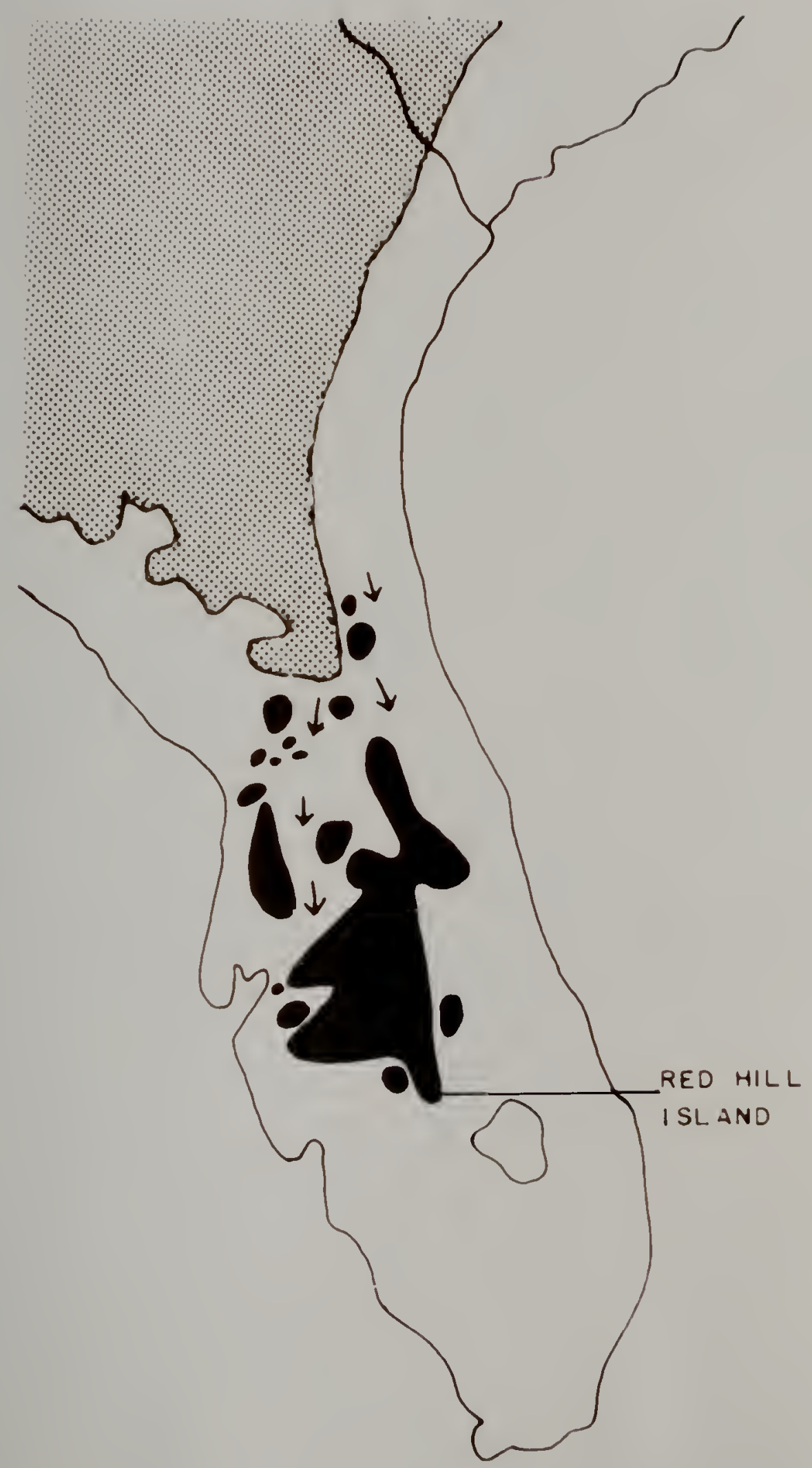


Figure 13. The approximate shore line of the Pamlico Sea superimposed on the present shoreline of Florida and Georgia. This map is a modification of that of MacNeil. 


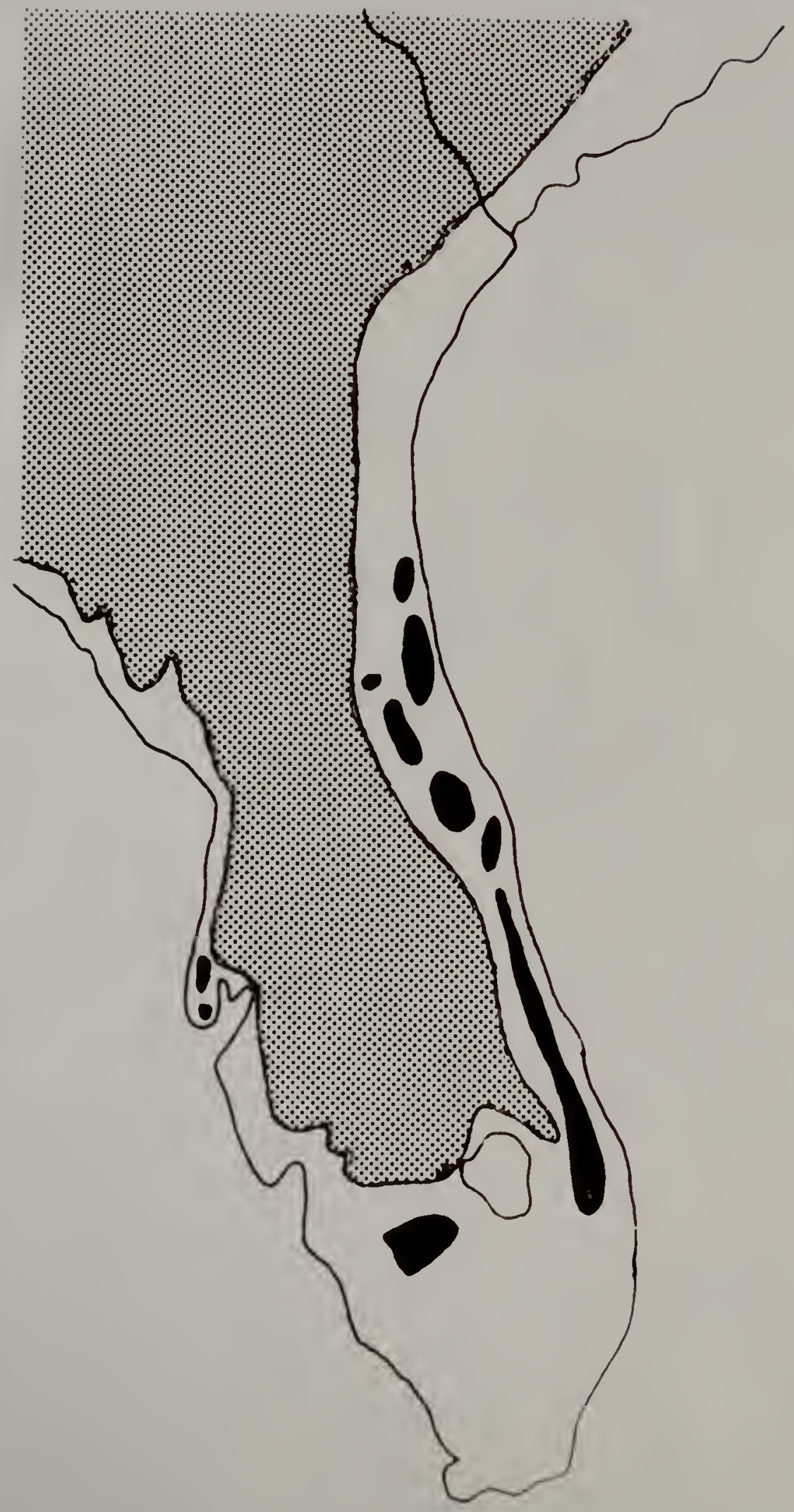


Table 12.-Estimated duration and associated shorelines of the Post-P1iocene Interglacial stages.

\begin{tabular}{llrr}
\hline Stage & $\begin{array}{l}\text { Associated } \\
\text { shoreline }\end{array}$ & $\begin{array}{l}\text { Altitude } \\
\text { in feet }\end{array}$ & $\begin{array}{c}\text { Duration } \\
\text { in years }\end{array}$ \\
\hline Aftonian & Okefenokee & 150 & 200,000 \\
Yarmouth & Wicomico & 100 & 300,000 \\
Sangamon & Pamlico & $25-30$ & 120,000 \\
Post Wisconsin & Silver Bluff & $8-10$ & 25,000 \\
\hline
\end{tabular}




\section{PRESENT DISTRIBUTION AND HABITAT RELATIONS}

Figure 14 shows the distribution of the pikel complex in Florida and Georgia. The range of pikel extends north to Massachusetts and is restricted to a narrow zone along the Atlantic coast. The distribution pattern that is shom for patellonigra and xera represents their actual distribution fairly accurately. Numerous collecting trips were made throughout Florida and southern Georgia. These trips were arranged so that the territory was traversed in an east-west as well as north-south direction. Therefore, the highly-restricted, north-south distribution pattern is a reflection of their actual distribution rather than an artifact brought about by the collecting method.

Emerton (1912) has described the habitats of pikel in New England. They are never found far from the seashore and are especially abundant in the sandy hills of Cape Cod. They are also found in the dunes just in back of the beaches. In Georgia and South Carolina, this species is found in sandhills which are as far as $90 \mathrm{miles}$ inland. However, these sandhills are located in an area which was traversed by shorelines during the Pleistocene.

Although patellonigra and xera are confined to areas in Florida which have deep, well-drained, sandy solls, not all such areas have been colonized. There are three different kinds of habitats which have this type of sandy soll. They are the sandhills, sand-pine scrubs and the active dunes of the coastal beaches. Neither patellonigra nor 
Figure 14. Distribution of the members of the pikei complex in Florida and Georgia. 


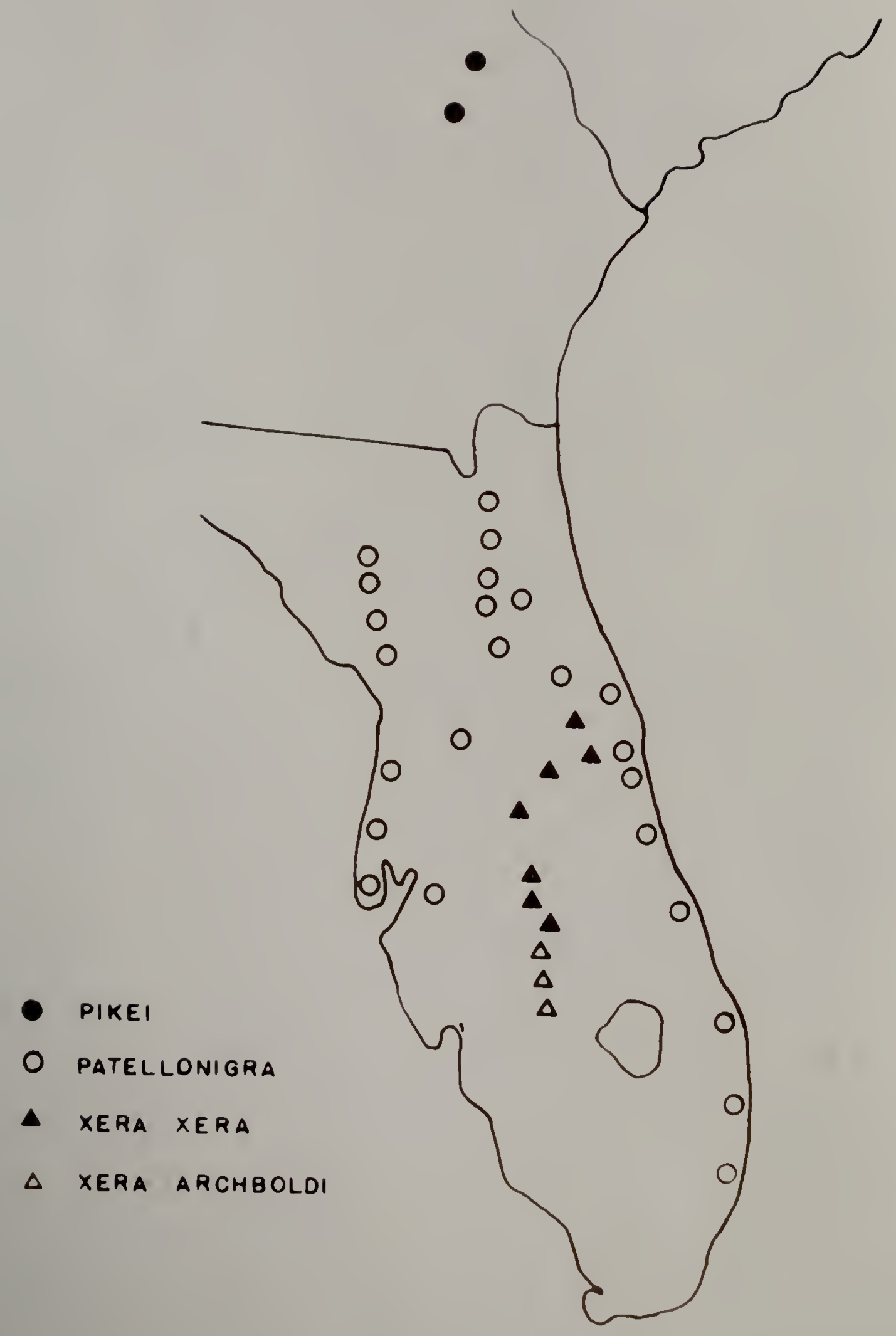


xera have been found inhabiting the active dunes. These dunes have been colonized by $\underline{G}$. micanopy Wallace, a widespread species in Florida which is found in many types of habitat. The sandhi11s and sand-pine scrubs are the only habitats from which patellonigra and xera have been taken. The sand-pine scrubs are found on the nutrient-poor soils of the St. Lucie and Lakewood series. The surface of both of these soils consists of white, beach-1ike sand. The vegetation is xeromorphic and is dominated by the sand-pine, Pinus clausa. Beneath the pines there is a dense growth of evergreen shrubs but little or no herbaceous ground cover. Areas of bare white sand are sometimes encountered.

The sandhill vegetation is found on soils of the Lakeland series. Longleaf pine (Pinus australio) and turkey oak (Quercus laevis) are the dominant trees and form open park-like stands. In Florida, however, there are few virgin stands since most of the pine has been logged off. The wire grasses, Arlstida stricta and Sporobolus gracilis, form most of the herbaceous ground cover. For a more complete description of these vegetation types see Harper (1914, 1915 and 1921), Cooke (1939), Kurz (1942) and Laessle (1942, 1958).

Although the sandhill and scrub areas are the only habitats in which patellonigra and xera are found, not all of these areas have been colonized. The reasons for this appear to be partly ecological and partiy historical. A consideration of the distribution of these species in the sand-pine scrubs will illustrate the effect of these ecological and historical factors.

Laessle (1958) has discussed the origin of the soils supporting these sand-pine scrubs. He reported that they apparently arose in 
the following ways: 1) Dunes, beaches and bars associated with PostPliocene marine shorelines. 2) Submerged hilltops in the Pleistocene seas. 3) Sand deposits washed and corted by deep marine currents of the Pleistocene seas. 4) Wave-washed shores of fresh-water lakes. A1though extensive collecting wa done in scrubs of all these types, only two types were found to be colonized by patellonigra and xera. The bulk of the specimens were collected from dune scrubs. If they had a rolling dune-1ike topography, scrubs formed on the washed and sorted, marlne, sand deposits also yielded specimens. This restriction to scrubs with a dune-1ike topography appears to be due to ecological rather than historical factors. In areas where dune-like and flat 8 crubs lie immediately adjacent and no barriers to migration are evident, there has been no movement into the flat scrubs.

The apparent operation of an historical factor can be seen when the distribution of these species in the various dune scrubs is examined. No specimens have been taken from dune scrubs known to have been formed on the Post-Wisconsin, 8 to 10-ft. Silver Bluff shoreline. A1though of more recent origin, these scrubs appear to be ecologically similar to those formed on other Post-P1iocene shorelines. This absence of patellonigra and xera from the Silver Bluff scrubs is best seen in connection with the scrubs on the West Coast of Florida. On the East Coast it is difficult to separate the Pamlico and Silver Bluff deposits. The West Coast Silver Bluff scrubs are separated from those formed on the Pamlico shoreline by fairly wide areas of flatwoods which are subject to flooding and provide an unsultable habitat for these pecies. 
The best explanation for the absence of these spiders is that they have IImited dispersal powers and have not been able to reach these scrubs yet. All of the Silver Bluff scrubs that have been examined were found to be inhabited by $\underline{G}$. micanopy.

Very little information is avallable on the origin of the sandhills so it is difficult to assess the effect of the historical factor on the distribution of xera and patellonigra in this habitat. Extensive areas of Florida, especially in the northern half, are covered with sandhills, but the distribution of these species within these areas is very restricted. Those sandhill areas which have been colonized all show a rolling dume-like topography. On the tops of these dume-1ike ridges there are large open areas devoid of wire grass. The soil has been heavily leached, and in some areas the surface is covered with an almost white sand. Rosemary (Ceratiola ericoides), a plant which grows on the soils which support sand-pine scrub and other poor soils, is common in these areas. Patellonigra and xera inhabit the tops of the ridges but are replaced by micanopy in the surrounding flatter area where the wire grass is thicker. The ridges run for many miles in narrow north-south bands through the more typical sandhill vegetation. Their location and ecological appearance suggest that they were formed in connection wh Plelstocene shorelines but definite proof is lacking. 


\section{CONCLUSIONS CONCERNING THE EVOLUT IONARY}

HISTORY OF THE COMPLEX

The most striking aspects of the taxonomy and distribution of the pikel complex are the allopatric nature of the species and the extent of speciation and infraspecific variation in the southern part of the range. This situation is not unique to this complex. It has been found in several other groups of animals inhabiting the lower southeastern Coastal Plain. These include such diverse groups as the beetles of the genus Mycotrupes (Hubbe11, 1954), the grasshoppers of the puer group of the genus Melanopus (Hubbe11, 1932, 1956) and the snakes of the genus Stilosoma (Highton, 1956).

A11 of these groups share two common characteristics, 1iulted dispersal povers and a restricted habitat preference. The grasshoppers of the puer group of the genus Melanoplus are flightless and are found only in the sandhills of North Florida and in certain flatwood areas in South Florida. The beetles of the genus Mycotrupes are flightless and fossorial. They usually are found only in the sandhill areas. The onakes of the genus Stilosoma are fossorial and have been recorded from sandhilis, and-pine scrub and xeric hammock but are not common in the two latter associations.

The extensive subspectation or allopatric speciation shom by the piket complex and the other groups mentioned above is usually found only in insular areas or areas where there are formidable natural barriers. At the present time neither of these situations is character- 
istic of the lower southeastern Coastal Plain. However, there is ample evidence for the repeated existence of insular conditions during the Post-Pliocene period. Both of the workers cited above came to the conclusion that the present distribution and taxonomic relationships of their groups could best be understood when correlated with this PostP1iocene insulation.

The pikei complex is a particularly favorable group in which to study this correlation. In the southern part of its range it is restricted to habitats which were formed in connection with the PostP1iocene shorelines. A1so all the available evidence indicates that these spiders have limited dispersal powers. They are fossorial and spend their entire life in the same burrow, enlarging it as they grow older. The only opportunity for dispersal would be when the young leave the mother's burrow. It is possible that they could disperse by ballooning at this time, but these spiders have two characteristics which would tend to negate this view. They form small and very localized colonies even though there are large areas of apparently suitable habitat between the colonies, and the burrowe of the young immatures tend to be clustered about the burrows of the old females. The absence of xera and patellonigra from the seemingly ecologically suitable Silver Bluff scrubs furnishes additional evidence of their 1imited dispersal powers. Some of the scrubs are located only about 30 miles from inhabited Pamlico scrubs. Although the spiders have had several thousand years to disperse to these scrubs, and although the prevailing winds are favorable, colonization has not occurred. 
The following account of the evolutionary history of the pikei complex is of course hypothetical, and alternative proposals are possible. It does, however, provide an explanation for the present distribution and taxonomic status of the complex which is consistent with the available geological data.

I can be postulated that during the P1iocene and the Nebraskan Glacial tage when Florida was a peninsula, a homogeneous ancestral stock inhabited the entire Atlantic seaboard. The rise in sea level during the following Aftonian Interglacial stage inundated large parts of Florida and Georgia and caused three relatively large populations to become isolated from this ancestral stock and from each other. Each of these three populations was confined to an island or island group in the Okefenokee Sea (Figure 11). One population inhabited the Trail Ridge island group and possibly the Tampa Bay island group also, another inhabited the Lake Wales island group, and the third was confined to Red Hill Irland. The strong currents of the Okefenokee Sea served as formidable barriers separating these populations. In view of the limited dispersal powers and narrow habitat restriction of these spiders, there was probably little movement of these populations from their Aftonlan centers of distribution when the water receded during the following Kansan Glacial stage.

Since the rise in sea level during the next Interglacial, the Yarmouth, was not as extensive, the Trall Ridge island group remained incorporated into the mainland and Red Hill Island was attached to the large Central Florida island of the Hicomico Sea (Figure 12). This large island was separated from the mainland by strong marine currents. 
A1though the Trail Ridge group formed part of the mainland, little gene flow was possible between the ancestral mainland population and the Tra11 Ridge population because of the presence of extensive swampland in the area which separated the Trail Ridge island group from the mainland during the Okefenokee period. However, because of the land connection and absence of swampland there was opportunity for gene flow between the populations on the Lake Wales Ridge and Red Hill IsIand. At the end of the Yarmouth Interglacial, there were three major populations which had been isolated from one another since the Aftonian Interglacial. One inhabited the mainland north of the Okefenokee Swamp, and another the area about the Trail Ridge, while the third was located in the Lake Wales Ridge area. During this period of isolation these populations achieved the specific status now represented by plkei, patellonigra and xera, respectively.

During the Aftonian Interglacial the population which differentlated into xera was separated into a northern and southern segment. The northern portion inhabited the Lake Wales Ridge island group, the southern the Red Hill Island. Although these areas have been reunited since that period, these tro segments presumably attained subspecific status during this period of isolation and are now represented by the subspecies xera and archboldi.

Al1 through the Sangamon Interglacial stage and up to the present time, the areas inhabited by patellonigra and xera have remained in contact. During this period, these species extended their ranges northward and southward from their centers of origin. The 
northern movement of patellonigra was halted by the unfavorable habitant in southern Georgia while the southern movement of xera was halted by the swampy Everglades region. In Central Florida these two species came into contact, but they have similar habitat requirements, and the competition at their lines of contact has maintained their original allopatry. However, patellonigra was able to move southward around the range of xera by utilizing the chain of Pamlico islands which lay along each coast (Figure 13).

An idea of the approximate amount of time available for the events discussed above can be obtained from Table 12. The chronology given in this table is based on the assumption that the last glacial drift sheet is 25,000 years old. Recent radioactive dating methods place this figure considerably lower (FIint, 1957), therefore, this chronology should only be used to get a general idea of the order of magnitude of the time involved.

As is suggested above, a strong case can be made to substantiate the thesis that the southern species and subspecies of the pikei complex differentiated on Pleistocene 1slands. If this theory is accepted, one important question remains unanswered. By what genetic mechanism was this differentiation brought about?

One possible mechanism would be genetic drift. If this had been operative, it would have to be assumed that the populations on the P1eistocene iolands were quite small. This assumption seems unwarranted if the number of individuals now inhabiting areas similar in size and ecology to these Plelstocene islands can be used in judging former density. 
A more reasonable explanation would be one of those offered by Mayr (1954) to explain the conspicuous differences shown by many peripherally isolated populations. He pointed out that in a species with a widespread range, such as that of the ancestral stock of the pikei complex, there is a constant flow of genes and gene complexes from the central part of the range into the marginal populations at the periphery. These genes and gene complexes which are adaptive in the central part of the range may not be so in these marginal populations. Thus the outlying populations must constantly be making genetic adjustments which w1ll adjust the influx to the requirements of their own environments.

If these marginal populations become isolated from the main populations, as those in the southern part of the range of the ancestral stock of the pikei complex were during much of the Pleistocene, those genes and gene complexes which had flowed in from the main populations would disappear if they were not adaptive in the environment of the isolated populations. New gene comblnations would be formed which would be better adapted for the environments of these populations. Since the selective forces and the results of the mutational process would be different in each population, this would lead to genetic divergence which could eventually result in the establishment of reproductive isolation and of speciation. 


\section{LITERATURE CITED}

Alexander, R. D. and R. S. Bigelow 1960. Allochronic speciation in field crickets, and a new species, Acheta veletis. Evolution, $14(3): 334-346$.

Brown, W. L. and E. 0. Wilson 1956. Character displacement. Syst. Zoo1., 5 (2): 49-64.

Barnes, R. D. 1959. The lapidicina group of the wolf spider genus Pardosa. Amer. Mus. Novitates, 1960: 1-20.

Carr, A. F., Jr. 1940. A contribution to the herpetology of Florida. Gainesville: University of Fla. Press, Biol. Sci. Series III (1): $1-118$.

Cooke, C. W. 1939. Scenery of Florida as interpreted by a geologist. F1a. Geo1. Surv. Bu11., 17: 1-118.

- 1945. Geology of Florida. Ibid., 29: 1-339.

Emerson, A. E. 1949. Ecology and isolation. (pp. 605-630 in Principles of Animal Ecology by Allee et al., Philadelphia and London: W. B. Saunders Co. 837 pp.).

Emerton, J. H. 1912. Four burrowing Lycosa (Geolycosa Montg., Scaptocosa Banks) including one new species. Psyche, 19: 25-36.

Flint, R. F. 1957. Glacial and Pleistocene Geology. New York: John Hiley and Sons. $553 \mathrm{pp}$.

Gabbutt, P. D. 1959. The biononics of the wood cricket, Nemobius sylvestris (Orthoptera: Gryllidae). Jour. Animal Ecol., 28 (1): 15-42.

Harper, R. M. 1914. Geography and vegetation of northern Florida. Fla. Geol. Surv., 6th Ann. Rept., 163-451.

- 1915. Vegetation types; natural resources in an area in central Florida. Ibid., 7th Ann. Rept., 135-188.

. 1921. Geography of central Florida. Tbid., 13th Ann. Rept., 71-307. 
Highton, R. 1956. Systematics and vartation of the endemic Florida snake genus Stilosoma. Fla. State Mus. Bull., 1 (2): 73-96.

Hubbe11, T. H. 1932. A revision of the puer group of the North American genus Melanoplus with remarks on the taxonomic value of the concealed male genitalia in the Cyrtacanthacrinae (Orthoptera, Acrididae). Misc. Pub1. Oniv. Mich. Mus. Zool., 23, 1-64.

- 1954. Relationships and distribution of Hycotrupes. (pp. 39-51 in The burrowing beetles of the genus Mycotrupes by A. L. 01son et a1. Misc. Publ. Univ. Mich. Mus. 2001., 84: 1-59).

- 1956. Some aspects of geographic varlation in insects. Ann. Rev. Entomology, 1: 71-88.

Kay, G. F. 1931. Classification and duration of the Pleistocene period. Geol. Soc. America Bull., 42, 425-466.

Kurz, H. 1942. Florida dunes and scrubs, vegetation and geology. Fla. Geol. Surv., Geo1. Bu11., 23, 1-154.

Laessie, A. M. 1942. The plant communities of the Welaka area. Gainesville: University of Fla. Press, Blol. Sol. Series, IV (1): 1-143.

- 1958. The origin and successional relationshtp of sandhill vegetation and sand-pine scrub. Eco1. Monog., 28, 361-387.

MaoNe11, F. S. 1950. Plelstocene shorelines in Florida and Georgia. J. S. Geol. Surv. Prof. Paper, 221-Fi 95-107.

Maerz, A. J. and M. R. Paul 1930. Dictlonary of Color. New York: MCGraw-H111. 207 pp.

Mayr, E. 1942. Systematics and the Origin of Species. New York; Columbia Univ. Press. $334 \mathrm{pp.}$

- 1954. Change of genetic environment and evolution. (pp. 157180 in Evolution as a Prooess ed. by J. S. Huxley et al., London: Geo. Allen and Unwin Ltd. 367 pp.).

, E. G. Linsley and R. L. Usinger 1953. Methods and Principles of Systematic Zoology. New York: McGraw-Hi11. 328 pp.

Montgomery, T. H. 1904. Descriptions of North American Araneae of the families Lycosidae and Pisauridae. Proc. Acad. Nat. Sc1. Phi1., 56, 261-323. 
Nei11, W. T. 1957. Historical biogeography of present day Florida. F1a. State Mus. Bu11., 2: 175-220.

Simpson, G. G., A. Roe and R. C. Lewontin 1960. Quantitative Zoology. New York: Harcourt, Brace and Co. 440 pp.

Wallace, H. K. 1942. A revision of the burrowing spiders of the genus Geolycosa (Araneae, Lycosidae). Am. Midl. Nat., 27: 1-62.

- 1942. A study of the 1enta group of the genus Lycosa, with descriptions of new species (Araneae, Lycosidae). Amer. Mus. Novitates, 1185; 1-21. 


\section{BIOGRAPHICAL SKETCH}

John David McCrone was born November 9, 1934, at Somerville, Massachusetts. In June, 1952 he was graduated from Concord High Schoo1. From 1952 to 1954 he attended Northeastern University, Boston, Massachusetts. In 1954 he trangferred to the University of Florlda, where he received his Bachelor of Science degree in 1956. He entered the Graduate School in the University of Florida the same year. Here he held a research assistantship and pursued studies in biology and biochemistry. In 1957-1958 he served in the United States Army. He re-entered the University of Florida in 1958 and held graduate and teaching assistantships and pursued studies in biology and entomology. In 1960-1961 he held a fellowhip from the Southern Regional Fund.

John David McCrone is married to the former Hazel Marle Dixon. He is a member of the Association of Southeastern Biologists, Phi Sigma Honorary Biological Society and the Newell Entomological Society. 
This dissertation was prepared under the direction of the chairman of the candidate's supervisory committee and has been approved by all members of that comittee. It was submitted to the Dean of the College of Arts and Sciences and to the Graduate Council, and was approved as partial fulfillment of the requirements for the degree of Doctor of Philosophy.

August 12,1961

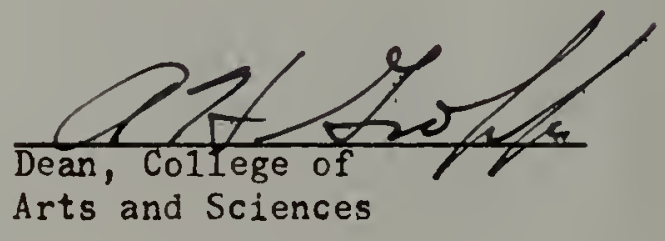

Dean, Graduate School

Supervisory Comnittee:
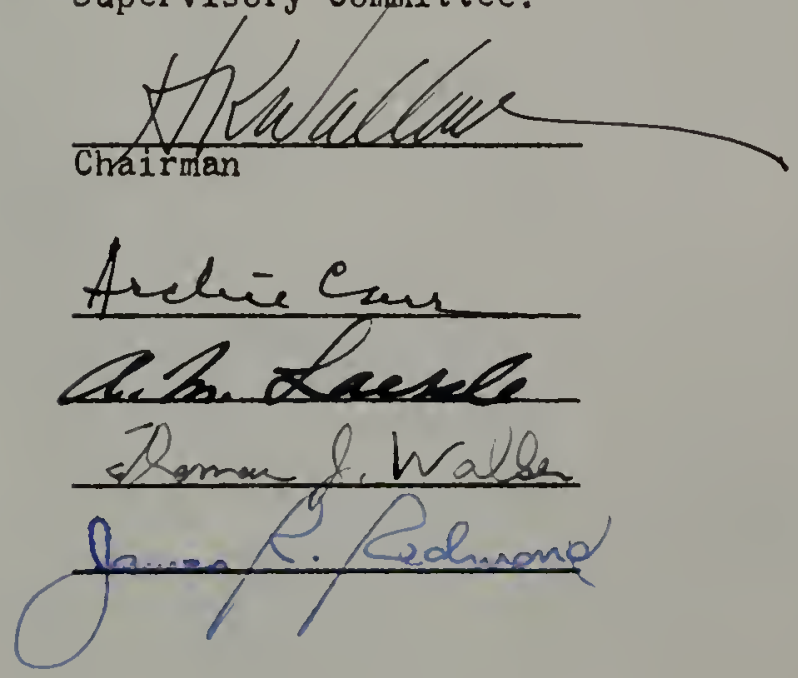